\title{
Seeking Unanimous Consent \\ Consensus Government in the Northwest Territories
}

By Stephen J. Dunbar, B.A.H.

\author{
A thesis submitted to \\ the Faculty of Graduate Studies and Research \\ in partial fulfillment of \\ the requirements for the degree of \\ Master of Arts
}
Department of Political Science
Carleton University
Ottawa, Ontario
Canada

(C) Stephen J. Dunbar, 2008 


$\begin{array}{ll}\begin{array}{l}\text { Library and } \\ \text { Archives Canada }\end{array} & \begin{array}{l}\text { Bibliothèque et } \\ \text { Archives Canada }\end{array} \\ \begin{array}{l}\text { Published Heritage } \\ \text { Branch }\end{array} & \begin{array}{l}\text { Direction du } \\ \text { Patrimoine de l'édition }\end{array} \\ \begin{array}{l}\text { 395 Wellington Street } \\ \text { Ottawa ON K1A ON4 } \\ \text { Canada }\end{array} & \begin{array}{l}\text { 395, rue Wellington } \\ \text { Ottawa ON K1A 0N4 } \\ \text { Canada }\end{array}\end{array}$

Your file Votre référence ISBN: 978-0-494-43456-7

Our file Notre référence

ISBN: 978-0-494-43456-7

NOTICE:

The author has granted a nonexclusive license allowing Library and Archives Canada to reproduce, publish, archive, preserve, conserve, communicate to the public by telecommunication or on the Internet, loan, distribute and sell theses worldwide, for commercial or noncommercial purposes, in microform, paper, electronic and/or any other formats.

The author retains copyright ownership and moral rights in this thesis. Neither the thesis nor substantial extracts from it may be printed or otherwise reproduced without the author's permission.
AVIS:

L'auteur a accordé une licence non exclusive permettant à la Bibliothèque et Archives Canada de reproduire, publier, archiver, sauvegarder, conserver, transmettre au public par télécommunication ou par l'Internet, prêter, distribuer et vendre des thèses partout dans le monde, à des fins commerciales ou autres, sur support microforme, papier, électronique et/ou autres formats.

L'auteur conserve la propriété du droit d'auteur et des droits moraux qui protège cette thèse. $\mathrm{Ni}$ la thèse ni des extraits substantiels de celle-ci ne doivent être imprimés ou autrement reproduits sans son autorisation.
In compliance with the Canadian

Privacy Act some supporting forms may have been removed from this thesis.

While these forms may be included in the document page count, their removal does not represent any loss of content from the thesis.
Conformément à la loi canadienne sur la protection de la vie privée, quelques formulaires secondaires ont été enlevés de cette thèse.

Bien que ces formulaires aient inclus dans la pagination, il n'y aura aucun contenu manquant.

\section{Canada}


Seeking Unanimous Consent

\title{
Consensus Government in the Northwest Territories
}

By Stephen J. Dunbar, B.A.H.

\author{
A thesis submitted to \\ the Faculty of Graduate Studies and Research \\ in partial fulfillment of \\ the requirements for the degree of \\ Master of Arts
}
Department of Political Science
Carleton University
Ottawa, Ontario
Canada

(c) Stephen J. Dunbar, 2008 


\section{TABLE OF CONTENTS}

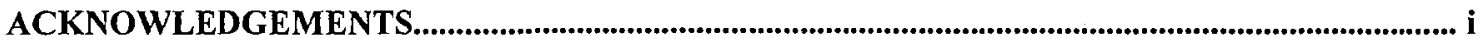

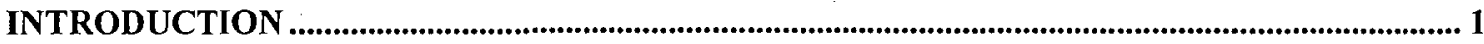

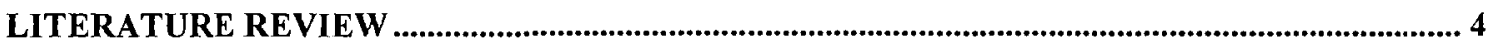

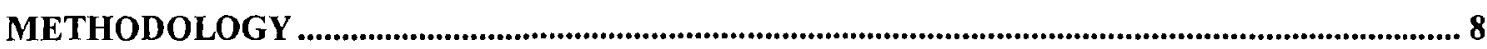

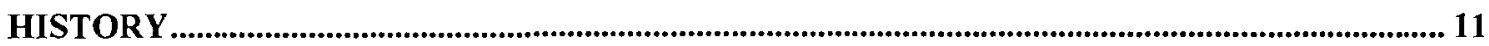

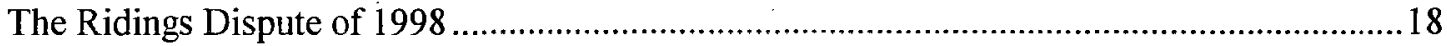

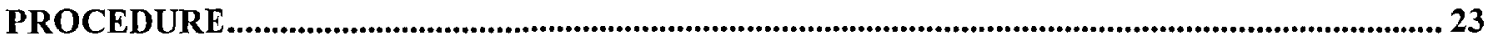

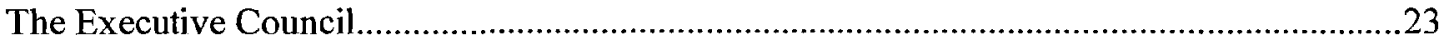

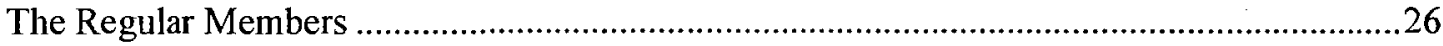

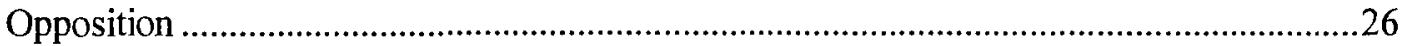

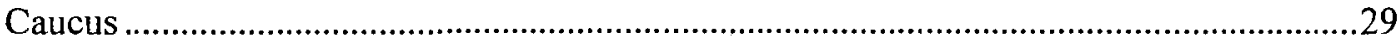

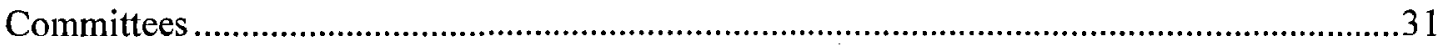

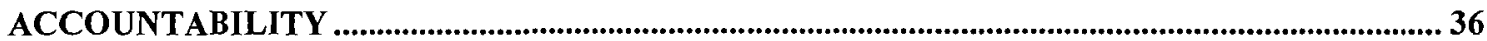

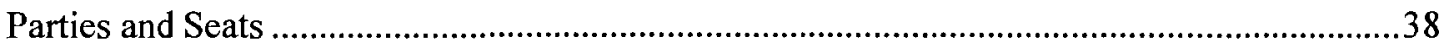

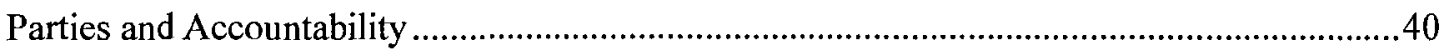

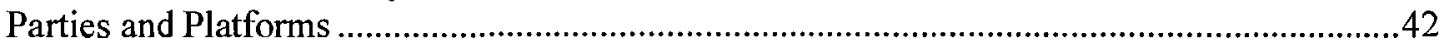

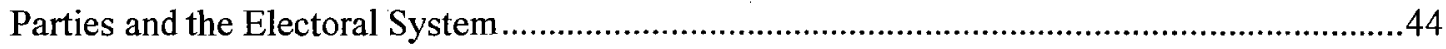

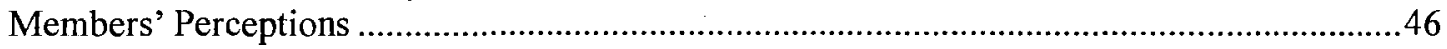

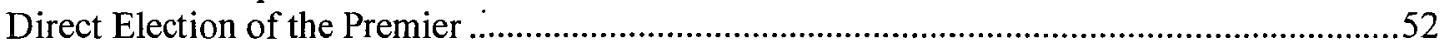

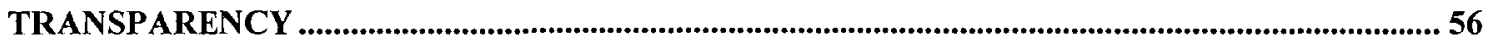

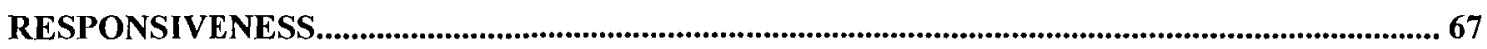

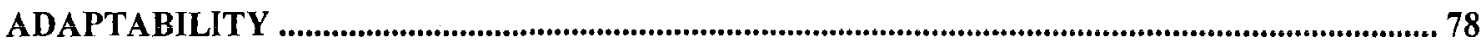

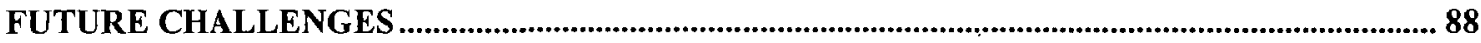

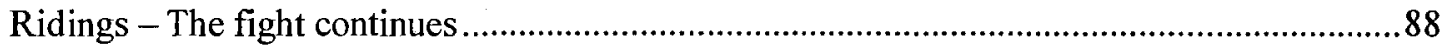

Land Claims and Self Government - What does this mean? ...........................................92

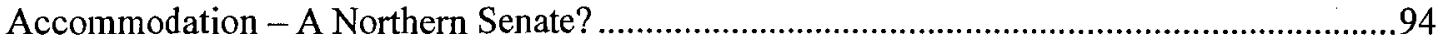

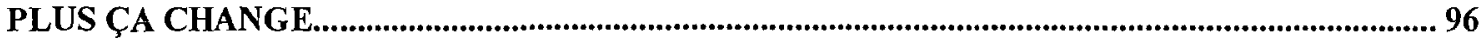

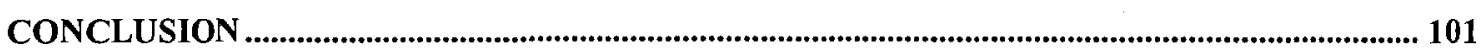

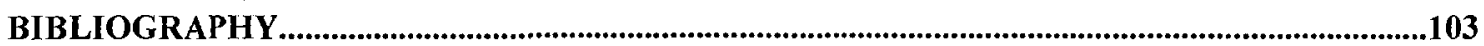




\section{Acknowledgements}

Over the course of my research, I have had the fortune of being assisted by many people.

First, my thanks to all the Members of the Legislative Assembly and their staff for accommodating and finding time to meet with me. Those same regards are also due to Commissioner Tony Whitford and his staff.

I would especially like to thank the Clerk of the Legislative Assembly, Tim Mercer, and his staff for all their help, especially Tanis Stirling, Haylee Brothers, Verna Currimbhoy and Vera Raschke.

For providing the results from his original research, Professor Graham White.

For opening their home to me once again, Tony and Terry Chang.

For the laughs, encouragement and help, David Hamilton and John Parker.

And finally, for their love, support, encouragement, and exceptional foresight, my parents, Linda and Blair, who first gave me the idea to write on consensus government. 


\section{Seeking Unanimous Consent \\ Consensus Government in the Northwest Territories*}

\section{Introduction}

The evolution of responsible government in the Northwest Territories has followed a course unlike that of any other jurisdiction in Canada. A combination of geography, demographics, culture, history, pragmatism and rapid development has created a political system styled consensus government. This system, while maintaining fundamental aspects of a Westminster parliamentary government, has made substantial adaptations to suit the peculiar needs of the territory. Of these, the most prominent is the absence of political parties within the Legislature, and the method in which the executive is thereby selected. The adaptations and inherent differences from more traditional government systems have led some to question the validity, accountability and effectiveness of consensus government.

In the late 1980s, Professor Graham White of the University of Toronto ${ }^{1}$ observed both the Legislative Assembly and its committees at work, conducted detailed interviews with the Members of the Legislative Assembly (MLAs), and had every MLA complete a questionnaire. His results have formed the basis of the only comprehensive study ever done on consensus government.

The Northwest Territories has undergone significant and dramatic changes since that research was published. From the division of the territory to create Nunavut and the

\footnotetext{
* As consensus government is the term used by its practitioners, it is the term that will be employed here to mean non-partisan Westminster cabinet-parliamentary government. References to East or West mean Nunavut and the current NWT respectively. Northern or Northerners is employed here to mean people of the NWT. Certain nouns are capitalized, notably Aboriginal, Cabinet, Regular Member and Minister as per the practice in the NWT.

${ }^{1}$ Graham White $a$, "Westminster in the Arctic: The Adaptation of British Parliamentarism in the Northwest Territories", Canadian Journal of Political Science, Vol. 24, no. 3 (Sept. 1991), pp.499-523
} 
western territory, the advancement of Aboriginal land claims and self government agreements, ${ }^{2}$ and rapid economic development of the natural resources, the political realities faced by the Legislative Assembly and its Members have resulted in consensus government undergoing many adaptations, some by choice, and others forced. While the consensus system remains, it is substantially altered from the system originally studied by Professor White.

Despite the changes, consensus government has retained strong support among those who work within it, and the general attitude of the people of whom it serves, there appears to be little appetite for change. ${ }^{3}$ In the research conducted for this paper, many MLAs could point to limitations or areas of concern within the system, however every MLA agreed that consensus government will continue to meet their needs in the future. Throughout the short history of responsible government in the Northwest Territories, the consensus system has provided effective and desirable governance, and that is likely to continue.

This paper is divided into chapters, each examining a different aspect of consensus government, and examining in particular if consensus government can provide effective, accountable governance. The history chapter will provide a brief overview of the evolution of responsible government in the Northwest Territories, as well as examining the factors that led to the adoption of the consensus system and the challenges it has withstood. Next will be Procedure, detailing how consensus government functions, including explanations of the roles of Caucus and Committees. The next four chapters deal with the results of questionnaire and interviews conducted with the Members.

\footnotetext{
${ }^{2}$ One such agreement, for the Tli Cho, has already been signed into law.

${ }^{3}$ Judging by election returns in the past three elections, where party candidates have faired very poorly.
} 
Accountability will deal with the mechanisms consensus government employs to remain accountable to the people of the Northwest Territories. In Transparency, the relationship between the Regular Members and the Executive Council will be examined, including the communication between the two groups and the influence of the Regular Members in the Legislative Assembly. Responsiveness will focus on the manner in which the Legislative Assembly develops policy and how it responds to the needs of Northerners. Finally in Adaptability, it will be argued that consensus is a derivation of the Westminster parliamentary system. Prior to the conclusion, there will be a brief discussion of the future challenges facing consensus government. 


\section{Literature Review}

Academic interest in the governance of the Northwest Territories has focused on the writings of three men in particular. Professor Gurston Dacks wrote several pieces on the future of consensus government in the territory in the 1980s. Professor Graham White followed, with his in-depth study of consensus government. Professor Mark Dickerson, in his book Whose North?, examined in detail the evolution of the government in the North and its potential future. Unfortunately, there has been little published since the early 1990 s.

Professor Dacks described consensus government in a 1985 paper as "an artifact of historical evolution and particular political circumstances." Furthermore, he predicted "[o]nce the fundamental issues are resolved, pressure from the South for the development of partisan politics will undoubtedly become significantly more compelling than it is currently." ${ }^{4}$ Despite this, he also stated that consensus would continue to have an important role to play in the political life of the territory, most importantly through the devolution of authority from the territorial government to the community councils. Dacks viewed consociationalism as the ideal system for the territory. In his article "Politics on the Last Frontier: Consociationalism in the Northwest Territories" Dacks described consociationalism as "a system of government and politics which recognizes constitutionally the ethnic, cultural or linguistic diversity within a liberal democracy, and provides each of the ethic, cultural or linguistic groups identified as enjoying collective

\footnotetext{
${ }^{4}$ Gurston Dacks, $a$, "Consensus Government in the Northwest Territories", presented to the Annual Meeting of the Canadian Political Science Association, Montreal, May 31 ${ }^{\text {st }}, 1985$. A copy of the speech was deposited with the Legislative Library in Yellowknife NT. Quotes from pp.17 and 19.
} 
rights within the polity the means to exercise and to safeguard these rights." ${ }^{.5}$ He suggests a few different ways by which this could be achieved. The first is by devolving to communities the "fullest jurisdiction they can manage and which will not enervate the territorial government." ${ }^{\prime 6}$ Dacks argues that a decentralized government with communities holding substantial decision-making authority will render the government more responsive to Aboriginal needs, and therefore more legitimate.

Consociationalism also addresses the Legislative Assembly, with some possibilities being the introduction of ethnically-designated representation, a Dene Senate with suspensive veto, guaranteed levels "of Aboriginal representation on land use and wildlife management agencies." 7 Dacks recognizes the need for all individuals "to be included in one of the cultural communities...because exclusion could deny basic human rights." He also states that such a system will require a "transformation of political thinking and organization [in the territory]." Should such a transformation prove impractical, infeasible or impossible, and the major ethnic groups cannot conduct territorial politics from a "minimally shared set of assumptions",10, he predicts the First Nations will separate themselves from the public government and pursue their own institutions.

The developments of recent years include a mixture of both Dacks' arguments. Consensus government has continued to operate as the de facto system of the Legislative Assembly, and self-government negotiations continue between the federal and territorial

\footnotetext{
${ }^{5}$ Gurston Dacks, $b$, "Consociationalism in the Northwest Territories", Canadian Journal of Political Science, Vol.19, No.2 (June 1986), pp.345-361, quote on p.357

${ }^{6}$ Ibid.

${ }^{7}$ Ibid p.358

${ }^{8}$ Ibid. p.359

${ }^{9}$ Ibid

${ }^{10}$ Ibid, p.361
} 
governments and Aboriginal groups, with the Tli Cho agreement being successfully concluded. Should the other negotiations result in similar agreements, the Northwest Territories will see a significant shift of powers and authority to the community or regional level. Just how this will impact the operation of consensus government remains to be seen.

Professor Mark Dickerson likewise argued for greater autonomy for the community or regional level. Again, it was felt that this would increase legitimacy in the eyes of Aboriginals. In quoting the Government of the Northwest Territories' Report on Regional and Tribal Councils in the Northwest Territories, "[t]he committee found that while the role of regional governments was principally 'advisory', many of the regional councils 'wanted to take over more authority for running programs of the Government of the NWT within the region."11 Furthermore, "while regional governments were interested in more 'program responsibility' in the region, they were not interested in 'law making powers held by the Legislative Assembly."12

Dickerson viewed this as a move towards a more county-style of regional government. A major difference he saw was that the regional councils in the NWT are made up of municipal officials chosen at the local level to represent their community on that council. This "conforms to the GNWT's idea of prime public authority at the local level." ${ }^{\text {13 }}$ He later argues that such a system may result in complicated funding arrangements that at the date of publication had not been resolved, but any solution would have to entail scrupulous accounting at each level.

\footnotetext{
${ }^{11}$ Mark Dickerson, Whose North?, UBC Press and the Arctic Institute of North America, Vancouver, 1992. p.183

${ }_{12}$ Ibid

${ }^{13} \mathrm{Ibid}, \mathrm{p} .184$
} 
While this work does not deal directly with the institution of consensus governance, the changes that self-governments will exact upon public government in the Northwest Territories will greatly influence how the Legislative Assembly will operate in the future. The methods by which the MLAs organize themselves to legislate, govern and decide upon the strategic course the territory will follow for the duration of the Assembly will be influenced by the local systems employed in the ridings. If consensus remains the 'minimally shared set of assumptions' that all groups agree to have as the basic system of governance in the Legislative Assembly, it may be the bond that holds the diverse population of the territory together. Similarly, if consensus over how the Assembly will operate proves impossible, the opposite may hold true. What seems likely is that the debate over how best to arrange power-sharing within the territory will continue.

Professor Graham White has been the most prolific author dealing directly with consensus government, with his original research from the late 1980s until after the division of the territories. Throughout, he has argued that "options beyond the status quo exist for the structuring and operation of the central institutions of governance...and that the effectiveness of these institutions depends in substantial measure on the extent to which they are meaningfully rooted in their societies."14 Consensus government is one such option, an adaptation of the Westminster system to meet the requirements of Northern society and customs. The findings of his research are frequently compared and discussed throughout this paper.

\footnotetext{
${ }^{14}$ Graham White $c$, "And Now For Something Completely Northern: Institutions of Governance in the Territorial North", Journal of Canadian Studies, Winter 2001; 35, 4, pp.80-99, p.81
} 


\section{Methodology}

Interviews were conducted over a six week period in Yellowknife between February and March of 2008. Seventeen of the nineteen MLAs were interviewed; two were unable to participate due to time constraints. The interviews were semi-structured. Each MLA was asked a series of questions determining their attitudes towards consensus government, its strengths and weaknessès, future challenges and overall effectiveness. All participants were guaranteed confidentiality, and as such, any quotations employed from the interviews will be non-attributable. The interviews lasted anywhere from fifteen minutes to an hour, with the average length being thirty minutes.

In addition to the interviews, every MLA was asked to complete a questionnaire. This questionnaire was derived from Professor White's original survey, with some additional questions created by the researcher. ${ }^{15}$ Sixteen MLAs responded. All results from the questionnaire are anonymous, and only the aggregate totals have been used here. The questions ranged from procedural matters to personal opinions on how the Assembly operates. All tables displayed in this paper, unless otherwise stated, are derived from this information. None of the current MLAs were participant in Professor White's study. It should be noted that not all respondents answered every question, with some Members checking more than one answer on certain questions, or none at all. In the case of multiple or missing answers, the percentages were calculated based on the number of respondents who only selected one option. An example of the table format is below.

\begin{tabular}{|l|l|l|c|c|c|c|c|c|c|}
\hline $\begin{array}{l}\text { Table } \\
\#\end{array}$ & Number & $\%$ & $\begin{array}{c}\text { White } \\
\%\end{array}$ & Minister & MLA & Aboriginal & $\begin{array}{c}\text { Non- } \\
\text { Aborig. }\end{array}$ & Urban & Rural \\
\hline Yes & & & & & & & & & \\
\hline No & & & & & & & & & \\
\hline
\end{tabular}

\footnotetext{
${ }^{15}$ Professor White sent the researcher a copy of his questionnaire along with the numerical results. One question was deleted, as it was no longer relevant.
} 
Number refers to the number of MLAs who selected that option, with the next column, $\%$, indicating what percentage that number corresponds to of all responses to that question. White \% displays the percentage of MLAs who responded to the same option in Professor White's survey. The Minister column displays the responses of the seven Members of the Executive Council, and MLA the responses of the Regular Members. Aboriginal and Non-Aboriginal columns break down the responses by ethnicity of the respondents. Members were asked to indicate which group they belonged to. The Urban and Rural columns divide the Members between the ridings of the largest centres and the communities. This was determined by selecting those communities with more than one Member to be urban ridings: Yellowknife, Hay River and Inuvik. All other ridings, even those with a greater population than an individual 'urban' riding, were placed in the rural category.

In addition to interviewing the MLAs, informal interviews were conducted with the current Clerk of the Legislative Assembly, Mr. Tim Mercer. The purpose of these interviews was to clarify procedural matters, and the opinions of Mr. Mercer were not sought. Staff with Elections NWT were contacted to discuss the Elections Act; this office also provided the researcher with copies of the Reports of the Chief Electoral Officer from every election since $1975 .^{16}$ Another informal interview was held with the current Commissioner of the Northwest Territories, Mr. Anthony Whitford, to discuss the role of his office in consensus government and the territorial government.

Two further interviews were conducted in Victoria, British Columbia. The first was with the former Clerk of the Legislative Assembly, Mr. David M. Hamilton, who

\footnotetext{
${ }^{16}$ The date of the first wholly elected Legislative Assembly, although full power was not derived to the Assembly from the Commissioner until the early 1980s.
} 
served in that office from 1983 until 2003. Questions to Mr. Hamilton dealt with procedural changes, and why those changes were implemented. The final interview was with Mr. John H. Parker, Deputy Commissioner of the Northwest Territories from 1967 until 1979, and Commissioner from that point until 1989. Mr. Parker was the last Commissioner to exercise significant power over the territorial government. He provided a detailed history of his former office, and the timeline for the devolution of power from the Commissioner to the Assembly, with the reasons and struggles behind those decisions. 


\section{History}

Responsible government in the Northwest Territories is still a relatively new concept. This chapter will explore how and why the consensus system was created to meet the unique challenges present in the North. It will provide a timeline for the devolution of power to the territory from Ottawa, the organization of an elected body composed of Northerners and the transformation of that body into a recognizable Westminster institution.

A local representative government was first established in the territory in 1888 , eighteen years after the purchase of Rupert's Land from the Hudson's Bay Company. ${ }^{17}$ This vast territory then comprised what today form the territories of the Yukon and Nunavut, the provinces of Alberta, Saskatchewan and the majority of Manitoba, as well as significant portions of Ontario and Quebec. The federal government passed "An Act to Amend and Consolidate the Laws Respecting the Northwest Territories" in 1875, and this act remains the governing legislation for the Legislative Assembly of the Northwest Territories. $^{18}$

In 1897, full responsible government was achieved for the whole NWT, which "included control of public monies and autonomous control of the activities of the Legislative Assembly."19 The first Premier, Frederick Haultain, governed the territory in a non-partisan manner, thus establishing the first 'consensus government' in the territory. However, this was short lived, as when the provinces of Alberta and Saskatchewan were created in 1905 , the administration of the remaining territory reverted back to Ottawa,

\footnotetext{
${ }^{17}$ History in the Making: Under Northern Skies, The Legislative Assembly of the Northwest Territories, a collection of essays by various authors familiar with the institution, published by the Legislative Assembly of the Northwest Territories, 1999. P.2

${ }_{18}$ Ibid.

${ }^{19}$ Ibid.
} 
under the aegis of a Commissioner. While a Territorial Council was created to arbitrate the enlarging of the Ontario, Quebec and Manitoba boundaries in 1912, this Council remained largely dormant until 1921, when six members were appointed by the federal government. All six were civil servants based in Ottawa. ${ }^{20}$

It was not until 1947 that a Northern resident was appointed to sit on the Council of the Northwest Territories. Three years later, the NWT Act was amended to allow for three elected Members from the Mackenzie District of the Northwest Territories in an expanded Council of eight. ${ }^{21}$ These were the first elected Members on the Council since 1905, and the first time in seventy years that a session of the Council was held in the North. ${ }^{22}$ In 1966, three new Eastern Arctic ridings were added, and the number of elected Members on the Council for the first time outnumbered those appointed, seven to five.

Yellowknife had been selected as the new capital of the Northwest Territories in 1965, as recommended in the Carrothers Commission. The report tabled in the House of Commons had several recommendations about the future of the North, most were accepted by Parliament. This report "formed the basis for a gradual return to responsible government." 23 The civil service was moved from Ottawa to Yellowknife, and the newly appointed Commissioner, Stuart Hodgson, promptly relocated to the North.

While the first fully elected Council took office in 1975, most of the powers of administration remained with the Office of the Commissioner, indeed, "[t]he Assembly still had limited financial powers. While it approved the territorial budget, it could not make changes in spending priorities and decisions. It also felt restricted in the areas of

\footnotetext{
${ }^{20}$ History in the Making, p.3

21 The Mackenzie District was then comprised roughly of what today are the current boundaries of the NWT. A fourth riding was created in 1954

${ }^{22}$ History in the Making, p.3

23 History in the Making; p.4
} 
political, social and economic development in the North." 24 However, both the Commissioner and his Deputy were invited to sit with the Council "in formal session and in committee-of-the-whole because we still had the majority of departments answering directly to us, so it was necessary for us to be there to provide information and explain our programs." 25 The Commissioner remained the chief executive of the territory until the start of the $9^{\text {th }}$ Assembly, beginning in 1979.

Throughout its entire history, the Territorial Council was operated consensually, and with the entire Council elected in 1975, all Members had been elected as independents. Only two of the fifteen Members were authorized by the federal Minister of Indian and Northern Affairs Canada (INAC) ${ }^{26}$ to join the Executive Committee, chaired by the Commissioner and rounded out by the Deputy Commissioner and an Assistant Commissioner. The two elected Members on the Executive Committee had been chosen by the full caucus of the elected Members. ${ }^{27}$ This began the tradition of having the House select its Cabinet Ministers. A third elected position was created on Cabinet a year later by order of the INAC Minister.

The $8^{\text {th }}$ Council was determined to exert greater independence from Ottawa, and as such, in 1976, declared by motion that the Council was henceforth to be known as the Legislative Assembly, and the Executive Committee members as Ministers, as was the case with provincial legislatures. Within a year, the INAC Minister had ordered the Commissioner to cease all use of these terms, calling them improper and unconstitutional. The proper names as set out in the NWT Act are the Territorial Council and Executive

\footnotetext{
${ }^{24}$ Ibid, p.62

${ }^{25}$ John H. Parker, Arctic Power, The Cider Press, Peterborough Ontario, 1992. P.65

${ }^{26}$ This Ministry has undergone many name changes, it is currently the Department of Indian Affairs and Northern Development.

${ }^{27}$ Ibid, p, 67
} 
Members. While the Commissioner and his staff complied briefly, "the rest of the people didn't, and through custom and precedent, the [new] terms stuck." ${ }^{28}$ In its last year the $8^{\text {th }}$ Council/Assembly issued a position paper on how to achieve responsible government, including having a reduced role for the Commissioner and an entirely elected Executive. Shortly thereafter, John H. Parker was named Commissioner, to succeed the retiring Hodgson. The two had worked closely in governing the territory, and while Hodgson had laid the groundwork, Parker brought true responsible government to fruition. ${ }^{29}$

1979 heralded a new era of change in the governance of the Northwest Territories. The NWT Act had been amended by Parliament, after being pressured by the territorial Assembly, to allow the Legislature to set its own number of Members, within the parameters of no fewer than 14 and no more than $25 .^{30}$ Thus the $9^{\text {th }}$ Assembly, elected in October of that year, had twenty-two Members, fourteen of whom were Aboriginal. INAC authorized the Commissioner to "invite the Legislature to select between five and seven of their number to sit on the Executive. ${ }^{.31}$ Parker invited seven Members, and the Executive was thus comprised of the seven, plus the Commissioner as chairman and the Deputy Commissioner. The Assembly decided upon the following procedure to choose the Cabinet:

Lacking party politics, there was no cut and dried way of selecting people. Before the opening of the first session, the members met in private caucus behind closed doors, the only non-member present being the Clerk of the Legislature who acted as chairman and vote counter. The members discussed who could best serve and what sort of balance or a regional nature should be maintained. In this instance, in 1979, the eastern members decided not to select Executive representatives...They were seeking some indication from the other members that Nunavut and

\footnotetext{
${ }^{28} \mathrm{Ibid}, \mathrm{p} .68$

${ }^{29}$ Interview with John Parker, April 7, 2008

${ }^{30}$ Parker, p.70, NWT Act, s. 9.2

${ }^{31}$ Parker, p.72
} 
division would be high on their agenda, and in fact they were not really prepared to move to Yellowknife...And so five members were chosen by secret ballot, all from the west, but with all members, including the easterners, voting...One year after this first session, the members from the eastern arctic were ready and in fact anxious to take up the two vacant executive positions, to utilize those positions of power. ${ }^{32}$

The Commissioner was still responsible for assigning portfolios. In 1980, the Executive raised in the Legislature whether there should be an elected Government Leader. The majority of Members were reluctant to give one person that kind of power, although they did name George Braden, a Member from Yellowknife, as the Leader of the Elected Executive, and in 1983, Braden became the Deputy Chairman of the Executive, replacing the role of Deputy Commissioner. The Deputy Commissioner ceased sitting on the Executive Committee later that year. ${ }^{33}$

Parker devolved control over the territorial finances to an elected Member in 1983, by relinquishing his role as Chairman of the Financial Management Board. He did so, however, without the approval of Ottawa, which viewed control over territorial finances, through the federally appointed Commissioner, as crucial. He was instructed, in a chastising letter from the INAC Minister, that he could devolve no further powers without federal Ministerial instruction. ${ }^{34}$ Later that year, the $10^{\text {th }}$ Assembly was elected, and at the first caucus meeting, Richard Nerysoo was elected by his colleagues to be the Government Leader, the first instance where the Legislative Assembly determined an elected head of government. ${ }^{35}$ Parker continued to chair Executive meetings, with Nerysoo as his deputy, and in one early meeting, he recommended that the Executive Committee be restyled as the Executive Council, the formal title of Cabinets elsewhere.

\footnotetext{
32 Ibid, pp.72-73

${ }^{33}$ Ibid, pp.73-74

${ }^{34}$ Ibid.

${ }^{35}$ Nerysoo was also the first Aboriginal to lead an elected government in Canada.
} 
Although this term is not recognized under the NWT Act, it has remained in use to this day. $^{36}$

After selecting the Executive Members in 1983, the Caucus decided upon a midterm review, to take place after two years, of the performance of the Ministers. "The reason for the review was twofold: first, to examine how well Executive Members were performing, and secondly, there was a view that the opportunity enjoyed by seven or eight people to be 'the government' should be passed around. With no political party to influence Cabinet, those MLAs not on the Executive often felt rather powerless." ${ }^{37}$ The mid term review of 1985 resulted in Nerysoo being removed as Government Leader, and one Minister was likewise not returned. The reason cited was lack of commitment.

Negotiations between the, Executive Council and the federal Minister of INAC resulted in the new Government Leader, Nick Sibbeston, taking over the chairmanship of the Executive Council. The Commissioner also relinquished the last portfolio that reported directly to him. Parker continued to attend Executive meetings in an advisory capacity, before withdrawing entirely in November 1987 , at the start of the $11^{\text {th }}$ Assembly. ${ }^{38}$ From that point forward, the Commissioner fulfilled a role more akin to that of a provincial Lieutenant Governor.

By the start of the $11^{\text {th }}$ Assembly in 1987, the Legislature had achieved actual, if not constitutional, responsible government. ${ }^{39}$ Conyentions had developed over the preceding twelve years allowing the Legislature to operate using a Westminster model,

\footnotetext{
${ }^{36}$ Parker, p.75

${ }^{37}$ Ibid.

${ }^{38}$ Interview with John Parker

${ }^{39}$ The NWT Act has never been amended to grant legislative or executive powers to the Legislative Assembly (Under the Act referred to as the Territorial Council). The Commissioner in Council holds all legislative power, as well as those of the Chief Executive. Sections 16-21 and s.3 respectively.
} 
but without political parties. These conventions included the election of the Government Leader and Executive Council members by secret ballot; the Caucus which comprised every Member, regardless of their position, in a in camera setting, allowing for frank discussion and compromise; and a regional balance between East and West, especially on the Executive Council, with four Members from the West and four from the East (the Government Leader being counted among the four). These conventions would remain in place until division in 1999 .

The years leading up to division were by no means tranquil. A territory wide referendum was held in May of 1992 to accept the proposed boundary between the two territories. ${ }^{40}$ While the boundary was approved by $54 \%$ of the votes cast, it was polarized between East and West. Overwhelming numbers voted yes in the East, and similarly, there was strong opposition in the West. However, the more populous West had poor turnout, with the average turnout in the four largest Western communities being well below $50 \%$, while the smaller communities of the East all had high turnout, with many surpassing $70 \%{ }^{41}$ The East-West divide had been among the greatest tests to consensus government. On one occasion in 1985, every Eastern Member, including those who sat on the Executive Council walked out of the House to prevent debate and voting on a proposed boundary that they did not favour. ${ }^{42}$ With Nunavut now almost a certainty, the tension between East and West lessened to a large degree. However, this raised new tensions amongst the Western Members.

\footnotetext{
${ }^{40}$ An earlier referendum was held on April 14, 1982 to agree to the creation of Nunavut.

${ }^{41}$ Report of the Chief Plebiscite Officer, Elections NWT, June 1992.

${ }^{42}$ Gurston Dacks, b, p.354, the incident is recorded in Hansard, February 25, 1985, pp.462-64
} 
With the imminent departure of the ten Eastern ridings, the Western territory ${ }^{43}$ would be left with fourteen Members, representing approximately 40,000 people. Yellowknife would then represent well over $40 \%$ of the entire population, but would only have four seats, or $29 \%$. A further cause for concern was the discrepancy in size between ridings. While the smallest remaining riding had just 625 electors, the largest riding in Yellowknife had 3,625 registered voters. ${ }^{44}$ To examine the situation and propose solutions, the Legislative Assembly created an Electoral Boundaries Commission in 1998. In their report, the Commission found unanimously that two new seats should be created in Yellowknife. They stated: "we have resisted a broad approach and have decided to recommend minimal changes at this time... We take the view that the population of Yellowknife and the principle of effective representation require additional seats for the city and therefore a redrawing of the electoral boundaries."

\section{The Ridings Dispute of 1998}

When the Boundaries Report came up for debate in the House in November of 1998, it became clear that there were fundamental divisions over the proposed changes. A debate was held in the Committee of the Whole where the Members represented only their ridings, and as such were free to vote as they saw fit. ${ }^{45}$ Some Members argued that giving Yellowknife more seats would alter the political balance consensus government requires to function, with one Member stating "Yellowknife, in my opinion, has most of

\footnotetext{
${ }^{43}$ An informal survey was conducted as to what the name of the Western Territory should be post-division. The majority chose to remain with Northwest Territories, although in a distant second place, the much ballyhooed Bob Territory.

${ }^{44}$ Electoral riding numbers taken from the 1995 Official Voting Results, published by the Chief Electoral Officer of Canada in his capacity as Chief Electoral Officer for the Northwest Territories. The smallest riding was [and still is] Tu Nedhe, then a population of 842, while the largest riding then was Yellowknife South, with 7,105 people.

${ }^{45}$ Hansard of the Legislative Assembly of the Northwest Territories, November 12, 1998, p.28
} 
the political cards. They have accessibility [to the Members] no one else has and have enjoyed for 30 years...the benefit of the huge machinery of government that is a presence in the North. ${ }^{46}$ Then Premier Don Morin, Member for the riding of Tu Nedhe, said "I heard somebody say...let the people have their say. Well, the people have had their say from $\mathrm{Tu}$ Nedhe and they said no more seats in Yellowknife...If there are any motions to be coming forward, I will be voting against any motions to give Yellowknife any more seats. ${ }^{.47}$

The Yellowknife Members spoke and voted in favour of the two additional seats, using different arguments. One argued for voter parity stating "I would like to point out right now Yellowknife has $26 \%$ of the population with $17 \%$ of the seats. We are only $9 \%$ off what we should be. If we stick with 14 seats, or four of 14, Yellowknife will have $44 \%$ of the population of the territory, with $29 \%$ of the seats...In fact, if we stay at four of 14 , we are diminished in our representation. ${ }^{48}$ Another argued that to function properly, the Assembly required a critical mass of at least 17 Members, relying on a paper submitted to the Commission by Professor White, "in which he argued that leaving the number of seats at 14 in fact constitutes a significant change to the current form of government. ${ }^{349}$ This point was argued most forcefully by Stephen Kakfwi, representing the rural Sahtu riding:

What we will end up with if we leave things as they are with 14, is we will have one Speaker, six Cabinet Ministers and, therefore, only seven Ordinary Members. The Cabinet could be able to call a session of this Legislature with only one Ordinary Member agreeing. That is only one who would have to attend these sessions for us to

\footnotetext{
${ }^{46}$ Hansard, November 12, 1998, p. 15

${ }^{47}$ Hansard, November 12, 1998, p.20

${ }^{48}$ Hansard, November 12, 1998, p.19

${ }^{49}$ Hansard, November 12, 1998 p.18
} 
carry on the business of this Legislature. That is a dramatic change in the nature, in the character of this institution. ${ }^{50}$

At the end of the debate, the motion to create two new ridings was defeated, as was a compromise proposed by a Yellowknife MLA to create one new riding for the city. The debate did highlight a growing division in the House. Where Professor White found the major division in the House as being along cultural-geographic lines, instead of structural or racial ${ }^{51}$, the growing division in the House, and indeed the predominant one today, is between the large centres and smaller communities. When asked what they see as the major division in the House, almost every Member stated the large-small divide as being the central division in the House today. ${ }^{52}$

With the rejection of additional seats by the Legislature, a group of concerned citizens sought to address the problem of the under-representation of Yellowknife residents. This group dubbed itself the 'Friends of Democracy', and sought legal advice with the financial backing of the City of Yellowknife. They were successful in bringing the matter before the Supreme Court of the Northwest Territories. In his ruling, delivered less than a month before division, Justice Mark M. de Weerdt found five ridings to be underrepresented, three in Yellowknife, the Inuvik riding and the Hay River riding. Every other riding was under the average population of $2,824 .{ }^{53}$ Citing a Supreme Court of Canada decision that section 3 of the Charter of Rights and Freedoms applies "not [to

\footnotetext{
${ }^{50}$ Hansard, November 12, 1998, p.20

${ }^{51}$ White $b$, "Structure and Culture in a Non-Partisan Westminster Parliament: Canada's Northwest Territories", Australian Journal of Political Science, 28:2, pp.322-339

${ }^{52}$ The question asked was "What do you see as the major division in the House today, is it linguistic, cultural, regional, racial, tax-based/non tax-based communities or something else?" Only the largest centres in the NWT are tax-based. Two Members provided other divisions.

${ }^{53}$ Friends of Democracy v. Northwest Territories (Commissioner) (1999) 171 D.L.R. $\left(4^{\text {th }}\right)$ 551, s. 12, accessed at http://www.canlii.org/en/nt/ntsc/doc/1999/1999canlii4256/1999canlii4256.html
} 
the] equality of voting power per se, but the right to effective representation." 54 As such, Justice de Weerdt ruled three ridings, Hay River, Yellowknife North and Yellowknife South to be invalid, and gave the Assembly until March 31, 1999 to rectify the situation.

The Cabinet acquiesced, and introduced Bill 15 to add a further three ridings to Yellowknife, and give both Inuvik and Hay River an additional seat each. During the same sitting, a motion was passed urging the government to appeal the ruling. The government declined to do so. As a result, the Committee on Government Operations held public meetings to discuss Bill 15. The Committee's report, detailing their consultations, included many statements from residents in smaller communities fearful of urban domination of the agenda. In particular, Nick Sibbeston, a former MLA and past Government Leader as well as a member of the 1998 Electoral Boundary Committee, stated "The Legislative Assembly will lose the support of the rural areas and native peoples. You will see the birth of political parties and we will lose our consensus style of government which is fashioned on the ways and approaches of the native peoples of the north." $" 55$ The Committee noted a "rift among Northern peoples" that this Bill would exacerbate. ${ }^{56}$ Along with the recommendation of a 'sunset clause', that the new seats would be in place only for the duration of the next Assembly; the Report also set forth a new Cabinet composition convention, similar to the East-West balance of pre-division Cabinets. In the next Assembly, the north, south and Yellowknife would each be entitled

\footnotetext{
${ }^{54}$ Ibid, s.9

${ }^{55}$ NWT Hansard, July 27, 1999, p.20

${ }^{56} \mathrm{Ibid}$.
} 
to two Ministerial seats. It was felt that this would ensure adequate representation for all regions. 57

Since 1999, the 2-2-2 convention for Cabinet has been utilized. While this guarantees equal representation on the Executive Council for the three regions, it does not ensure that large centres outside of Yellowknife have Members on the Executive Council. It does, however, ensure that the selection of Executive Members is conducted in a manner consistent with the consensus conventions developed over the previous decades. The consensus system has remained the sole process by which the Northwest Territories has been governed since the first introduction of representative, then responsible government.

\footnotetext{
${ }^{57}$ The northern ridings are those north of Great Slave Lake, the southern those to the south. Hansard, supra, p.22-23 The sunset clause was repealed by the $14^{\text {th }}$ Assembly (1999-2003)
} 


\section{$\underline{\text { Procedure }}$}

The consensus model has evolved as the system required. It has evolved to meet new challenges, adapted to changing realities, and responded to calls for greater accountability. It has been able to do so due to its ability to change procedures to suit the need. Among the changes are the process by which the Executive Council is selected, the organization of the Regular Members into the Committee system and the manner by which business is conducted in the House.

\section{The Executive Council}

The process for selecting the Premier, the term that replaced Government Leader during the $12^{\text {th }}$ Assembly under Nellie Cournoyea, has remained the same since 1980 . However, in 1991, both the Premier and Cabinet selection process was made public, under the auspices of the Territorial Leadership Committee. On the first day of business following the general election, the Members are called to the House to elect the Speaker, who will act as the Chair of the Leadership Committee. The Clerk calls for nominations from the floor, and the nominated Member has the opportunity to accept or decline. The candidates, if there is more than one, are allowed a five minute speech to state why they should be Speaker. A secret ballot ensues, with the Clerk as vote counter. If there is only one nomination, that person is acclaimed and immediately takes the Chair. The meeting of the Committee is thereafter adjourned to the next day.

Next the process for the election of the Premier is confirmed, with nominations again coming from the floor. Each candidate is permitted twenty minutes to speak. After 
the speeches, every Member is permitted to ask the candidates two questions. ${ }^{58}$ The questions range from territory-wide issues, to specific constituency concerns. After the question period, a secret ballot is conducted, again with the Clerk as vote counter. The Chair [Speaker] also casts a vote. Runoff ballots are used, with the lowest candidate being dropped if necessary. After a winner is declared, that individual is permitted a brief opportunity to address the House.

The method for nominating Ministers was changed most recently in 2007 . Where prospective candidates once had to be nominated, the Chair now calls for every Member from one region who wishes to stand for the Executive Council to rise. The Chair then names the Member as a nominee for the Executive Council. Each nominee is permitted ten minutes to speak, in alphabetical order, regardless of region. After the speeches are concluded, every Member, including the Chair and Premier-elect, receives three ballots, one for the North, the South and Yellowknife nominees. After voting in secret, the results are once again tabulated by the Clerk. In the event where no two Members from one region receive the majority of votes, a runoff ballot is held just for that region. The Chair announces that Members have been elected for the other regions, but a further ballot is required for ' $x$ ' region. If only one or none of the Members received a majority, the candidate with the fewest votes is dropped from the ballot. Nominees are given the opportunity to withdraw their names from contention prior to the second ballot. Once two nominees have received $50 \%$ plus one on one ballot, the Chair then announces to the House that they have elected these six nominees to the Executive Council.

\footnotetext{
${ }^{58}$ From 1991 until 2000, each Member was allowed to ask 4 questions. There were no questions asked in 2003 due to the acclamation of Joe Handley to the Premiership.
} 
Once elected, the Executive Council sits with the consent and at the pleasure of the House. It has not been uncommon for the Regular Members to unseat a Minister, and the Government Leader was removed from office in 1985, due to the Members feeling he lacked commitment. Unlike other parliamentary governments, the Premier does not have the power or authority to dismiss an Executive Member. The Premier does assign portfolios, and if displeased with a Minister, may remove the portfolios held and reassign them, indicating to the House that the Minister has lost the confidence of the Premier, but it is up to the House to revoke the appointment to the Executive Council.

While there is still strong opposition to having the Premier select his or her own Cabinet, a majority of Members feel that the Premier should have the power to dismiss a Minister from Cabinet in extreme circumstances as shown in the tables below:

\begin{tabular}{|l|c|c|c|c|c|c|c|c|c|}
\hline $\begin{array}{l}\text { Table } \\
1\end{array}$ & Number & $\%$ & $\begin{array}{c}\text { White } \\
\%\end{array}$ & Minister & MLA & Aboriginal & $\begin{array}{c}\text { Non- } \\
\text { Aborig. }\end{array}$ & Urban & Rural \\
\hline Yes & 5 & $31 \%$ & $25 \%$ & 1 & 4 & 1 & 4 & 4 & 1 \\
\hline No & 11 & $69 \%$ & $75 \%$ & 5 & 6 & 9 & 2 & 5 & 6 \\
\hline
\end{tabular}

Q: Do you think that the Premier should be able to pick his or her own Cabinet?

\begin{tabular}{|l|c|c|c|c|c|c|c|c|c|}
\hline $\begin{array}{l}\text { Table } \\
2\end{array}$ & Number & $\%$ & $\begin{array}{c}\text { White } \\
\%\end{array}$ & Minister & MLA & Aboriginal & $\begin{array}{c}\text { Non- } \\
\text { Aborig. }\end{array}$ & Urban & Rural \\
\hline Yes & 10 & $63 \%$ & --- & 2 & 8 & 5 & 5 & 7 & 3 \\
\hline No & 6 & $38 \%$ & -- & 4 & 2 & 5 & 1 & 2 & 4 \\
\hline
\end{tabular}

Q: Should the Premier have the power to dismiss a Minister from Cabinet?

\begin{tabular}{|l|c|c|c|c|c|c|c|c|c|}
\hline Table 3 & Number & $\%$ & $\begin{array}{c}\text { White } \\
\%\end{array}$ & Minister & MLA & Aboriginal & $\begin{array}{c}\text { Non- } \\
\text { Aborig. }\end{array}$ & Urban & Rural \\
\hline Extreme & 10 & $63 \%$ & $71 \%$ & 5 & 5 & 6 & 4 & 6 & 4 \\
\hline Any & 6 & $38 \%$ & $29 \%$ & 1 & 5 & 4 & 2 & 3 & 3 \\
\hline
\end{tabular}

Q: If the Premier did have the authority to dismiss a Minister, should this power only be used in extreme circumstances, such as clear cases of wrongdoing or major errors, or should the Premier be able to remove a Minister for any reason?

Interestingly, a majority of existing Ministers feel that it is better for the House to elect the Cabinet and have the power over their removal, whereas an overwhelming majority of the Regular Members feel that the Premier should be able to dismiss a 
Minister. This may be the case due to the acrimonious nature of removing a sitting Minister, and if successful, the deposed Minister then joins the Regular Members Caucus, in effect, sits with those who were responsible for ousting them from office. If the Premier had the power to remove a Minister from office, it could have the effect of lessening personal tensions between Regular Members. Furthermore, if Members felt that the Minister was not fired for adequate reasons, there is no barrier to them reelecting that individual to the Executive Council.

\section{The Regular Members}

The method for selecting Executive Council members and subsequently the Government Leader had been established in a non-partisan manner; however the role of the Ordinary Members was less defined. ${ }^{59}$ It is important to note that "private Members have opportunities for influence far beyond that enjoyed by their counterparts in other Westminster systems. ${ }^{, 60}$ This influence is exerted in several ways. These Members compose the unofficial opposition, sit on the committees of the House, and until division in 1999, many were also part of specific caucuses.

\section{Opposition}

There is no formal opposition under consensus government; indeed, unanimity is the ideal, if not the reality. Indeed, many observers are struck at the civility and courtesy extended to Members speaking in the House. ${ }^{61}$ During the 1980 s and early 90 s, even the term 'opposition' was studiously avoided. By 1987, the Ordinary Members Committee

\footnotetext{
${ }^{59}$ Non-Executive Council members were known first as Ordinary Members, until after division, when they became known as the Regular Members.

${ }^{60}$ White $c$, p. 84

${ }^{61}$ Susan Baldwin, "A Procedural Clerk Goes North", Canadian Parliamentary Review, Vol. 6, No. 31983
} 
(OMC) operated as an unofficial opposition, however, the preferred term for this group was 'Ajauqtit', an Inuktitut word meaning 'people who push' or 'pushing together', which is in reference to those who help push a sled that has bogged down in snow. ${ }^{62}$ The term now employed is the Standing Committee on Priorities and Planning. While Ajauqtit and now the Committee are not a party in the traditional sense, it does meet daily during session and elects a chairperson. Prior to each day's sitting, they choose what to question the government on and set priorities for debate and legislation. Although some worried that this was leading towards party politics,

"[i]n reality, however, the government acted more like a shifting coalition. Although there were no political parties there were other affiliations that bound people together just as strongly as political ties...A vulnerable Minister could often survive because the fifteen Ordinary Members sometimes had competing sympathies with a Minister under attack. He survived on the principle it was difficult to get all fifteen Members upset on one issue all at the same time." ${ }^{.63}$

While the Committee has the power to extend question period, debate or pass motions through its numerical superiority in the House, "the pragmatic view seems to be that when these twenty-four MLAs choose an executive, they also consent to the authority and leadership that the executive must exercise in order to properly run the government. ${ }^{\prime 64}$ Under this system, the executive governs with the consent of the House, rather than with the confidence. While votes of non-confidence are common, especially in minority governments, the situation in the Northwest Territories has developed

\footnotetext{
${ }^{62}$ Kevin O'Keefe, "Northwest Territories: Accommodating the Future", in Provincial and Territorial Legislatures in Canada, University of Toronto Press, Toronto, 1987, pp.207-220. Information taken from endnote 8, on page 240. Brian Lewis, a Member from 1987-1995, states that the acronym OMC to Inuit stood for Outboard Motor Company, and thus they preferred Ajauttit [sic]. Brian Lewis, "The Development of Responsible Government in the Northwest Territories 1976-1998" in Canadian Parliamentary Review, Summer 1998, Vol. 21 no.2 pp.12-17

${ }^{63}$ Lewis, p. 15

${ }^{64}$ O'Keefe, p.212
} 
differently. Over twenty years ago, it was believed that the Legislative Assembly would follow the southern example:

During the [1987 budget] session several motions were introduced in Committee of the Whole to delete or reduce funding allocations for various government programs. Elsewhere in Canada this might have precipitated the fall of an entire government and a subsequent general election, but not in the NWT. Although all the motions could be interpreted as non-confidence motions, there is nothing in the existing rules and practices of the legislature that would require the executive to resign, much less cause a general election. All the motions were defeated, so the real impact remains a matter of speculation. There would likely have been an expectation for the executive to resign, and if this happened, all twenty-four Members would retreat to Caucus to select a new executive. ${ }^{65}$

However, in the past two budget sessions, including that in May and June of 2008, the Regular Members did delete and reallocate funds from the budget without precipitating the fall of the government. This further throws into question the impact of the confidence convention under consensus government. The fact that the confidence convention has never been tested is indicative of the willingness by Cabinet and Regular Members to communicate problems and difficulties with legislation. In the following tables, Members were asked:

On routine and important issues of government policy, which come before the Legislature, would you say the government usually: A. Just tries to get the support of 4 or 5 MLAs, so that it is assured of having a majority in the House for its policy. B. Tries to get the support of as many MLAs as possible, but doesn't work all that hard at it once it has enough MLAs to ensure a majority for its policy or $\mathrm{C}$. Tries hard to get the support of all MLAs, even if it already has the support of enough MLAs to ensure a majority for its policy.

The results show clearly that the majority believe the Government attempts to get as many MLAs as possible to support both routine and important policies.

${ }^{65}$ Ibid. This was the procedural opinion of then Clerk David Hamilton. 
Table 4

\begin{tabular}{|l|c|c|c|c|c|c|c|c|c|}
\hline Routine & Number & $\%$ & $\begin{array}{c}\text { White } \\
\%\end{array}$ & Minister & MLA & Aboriginal & $\begin{array}{c}\text { Non- } \\
\text { Aborig. }\end{array}$ & Urban & Rural \\
\hline Just enough & 4 & $25 \%$ & $8 \%$ & & 4 & 2 & 2 & 2 & 2 \\
\hline As many as & 6 & $38 \%$ & $50 \%$ & 1 & 5 & 3 & 3 & 5 & 1 \\
\hline Tries for all & 6 & $38 \%$ & $42 \%$ & 5 & 1 & 5 & 1 & 2 & 4 \\
\hline Important & Number & $\%$ & $\begin{array}{c}\text { White } \\
\%\end{array}$ & Minister & MLA & Aboriginal & $\begin{array}{c}\text { Non- } \\
\text { Aborig. }\end{array}$ & Urban & Rural \\
\hline Just enough & 4 & $25 \%$ & $4 \%$ & 1 & 3 & 3 & 1 & 1 & 3 \\
\hline As many as & 4 & $25 \%$ & $33 \%$ & & 4 & 1 & 3 & 4 & \\
\hline Tries for all & 8 & $50 \%$ & $63 \%$ & 5 & 3 & 6 & 2 & 4 & 4 \\
\hline
\end{tabular}

While Members do appear less inclined to believe the Cabinet tries to get everyone on board compared to twenty years ago, the majority of Ministers state that they try to get everyone's support. Important policies are more likely to see greater efforts by Cabinet to get everyone to vote in favour. What is clear is that only a minority believe that the government tries to get only the bare minimum of support for both routine and important policies.

\section{$\underline{\text { Caucus }}$}

Currently there is one caucus in the NWT Legislative Assembly, comprised of every Member, regardless of where they sit in the House. However, prior to the division of the territory in 1999, several other caucuses existed. These included separate caucuses for the Eastern Arctic Members, the Dene-Métis Members, and later, every Member from the Western Arctic. ${ }^{66}$ The prevalence of these separate caucuses was of concern to some Members, leading former Government Leader and Speaker Richard Nerysoo to state, "We are headed in a direction that many people here do not like, and that is to set out

${ }^{66}$ Lewis, p.5 
caucuses of our own, governments similar to that of party politics. If people feel so strongly about the idea of consensus, then for God's sake lay on the table the concerns you have and speak to one another in terms where people can at least address the problems you want them to address." ${ }^{.67}$ However, the $14^{\text {th }}$ Assembly, the first postdivision, chose to retain only the full Caucus.

This Caucus is essential to the smooth operation of consensus government. It provides an in camera forum where every Member meets as equals, and can speak freely. The Clerk of the Legislative Assembly explained Caucus as the forum where the Legislative Agenda and House planning was set, disciplinary matters were settled, the operation of consensus government was discussed and changes to the Legislative Assembly Act and debates over pay were held. This is to ensure that the Cabinet is not seen as taking a position. The following table shows the results for: "Which statement better describes the way Caucus operates most of the time? Caucus is 19 individuals discussing problems and trying to find solutions or Caucus is a discussion between Cabinet and the Regular Members about government policy."

\begin{tabular}{|l|c|c|c|c|c|c|c|c|c|}
\hline Table 5 & Number & $\%$ & $\begin{array}{c}\text { White } \\
\%\end{array}$ & Minister & MLA & Aboriginal & $\begin{array}{c}\text { Non- } \\
\text { Aborig. }\end{array}$ & Urban & Rural \\
\hline Individuals & 13 & $81 \%$ & $83 \%$ & 5 & 8 & 8 & 5 & 8 & 5 \\
\hline Cab./Reg. & 3 & $19 \%$ & $17 \%$ & 1 & 2 & 2 & 1 & 1 & 2 \\
\hline
\end{tabular}

A strong majority of Members feel that Caucus is a venue for the individual MLAs to discuss problems and find solutions, outside of the House, and away from the structural division of the Executive and Regular Members. This view of Caucus has not changed much in the past 20 years. By sitting in Caucus as MLAs representing only their

\footnotetext{
${ }^{67}$ Hansard of the Territorial Leadership Committee, November 12, 1991, p.15
} 
constituency, and not a House role as Speaker, Premier or Minister, Members are able to express concerns to legislation or the budget that has not yet come before the House. Former MLA and Speaker of the Nunavut Legislative Assembly Kevin O'Brien stated:

Some questions can be decided in caucus, which may mean that debate in the House is limited, while on others agreement will not be reached and the discussions will continue in the House and in committees. I do not want to leave the impression that caucus is the real decision-making body and that it dictates to cabinet. It does not, but the discussions in caucus make it clear where everyone stands and facilitate compromises and problem-solving. ${ }^{68}$

In the more recent Assemblies, it has been in Caucus where Members have developed the 'Strategic Plan', a declaration of priorities for the Assembly to work towards achieving, and the direction that they foresee the territory embarking upon. Some Members expressed that they would evaluate Cabinet Members by their ability to follow and implement the Strategic Plan.

\section{$\underline{\text { Committees }}$}

Finally, the Regular Members sit on the Standing Committees of the Legislative Assembly. For a Legislature that has only 11 Regular Members, there are a surprising number of very active committees. There are three legislative standing committees: Government Operations, Social Programs, and Economic Development and Infrastructure. Each committee oversees various government departments and agencies, their budgets, performance and any other matter referred to committee by the House. Government Operations deals with the departments of the Executive, Human Resources, Finance and the Financial Management Board Secretariat. Social Programs oversees

\footnotetext{
${ }^{68}$ Kevin O'Brien, "Some Thoughts on Consensus Government in Nunavut", Canadian Parliamentary Review, Vol. 26, No. 42003 pp.6(5)
} 
Health and Social Services, Justice, and Education, and Culture and Employment. Economic Development looks at Aboriginal Affairs and Intergovernmental Relations, Environment and Natural Resources, Industry Tourisn and Investment, Transportation and the Northwest Territories Housing Corporation. ${ }^{69}$ Debates over legislation often take place in committee hearings.

The first order of business for the Regular Members following the Territorial Leadership Committee is to elect the committee Chairs. As is the case for the Executive Council, the Chairs are elected through successive secret ballots, with the candidate with the fewest votes being dropped until one candidate secures over $50 \%$. Although this is a remunerated position, these appointments are not ratified by the House to maintain the autonomy and authority of the committees. Once the Chairs are elected, they then form the Striking Committee, which recommends Members to committees, after ascertaining the Members' preferences. If there is consensus, committee membership is ratified by the House. It is often a delicate balance matching individual interests with regional and urban/rural representation..$^{70}$

This method of Chair selection is new to the $16^{\text {th }}$ Assembly. Prior to this, each committee would elect their Chairperson after the membership had been determined. Reform was advocated primarily in an attempt to curb absenteeism. The Striking Committee of the Chairs has the power to recommend expulsion from a committee, and it is hoped that this arrangement will be of sufficient influence to curb the problems of previous Assemblies.

\footnotetext{
${ }^{69}$ From the Legislative Assembly website, http://www.assembly.gov.nt.ca/ live/pages/wpPages/Committees.aspx

${ }^{70}$ Procedure of Chair election provided by the Office of the Clerk.
} 
One of the reasons that absenteeism is viewed as so problematic is that the Standing Committees in consensus government wield an extraordinary amount of power. In Nunavut, as in the NWT "they are routinely provided by Cabinet with confidential information that committees in Ottawa and the provincial capitals could only dream of receiving. This includes draft government legislation, departments' draft expenditure budgets and other confidential documents." ${ }^{, 1}$ This practice has been longstanding in the Legislature, with Professor White noting:

All government legislation is sent, in draft form, to the Assembly's Standing Committee on Legislation several weeks prior to its introduction in the legislature. The committee, which has its own legal counsel, reviews the draft bills with the sponsoring minister and may circulate copies to potentially interested groups for their comments. In this process substantial numbers of significant amendments come forward from the committee and are typically accepted by the government. On occasion, the committee proposes such wholesale changes that the government is forced to reconsider the whole enferprise. The government listens carefully to the concerns of the Ordinary Members and for the most part responds positively to them. ${ }^{72}$

White also notes that the budget is likewise sent to the committees in draft form, which is then reviewed line by line months before being presented to the House. This often results in substantial changes being made to the budget prior to its tabling. ${ }^{73}$

The committees also conduct community hearings across the territory, maintaining the early Assemblies practice of bringing government closer to the people. ${ }^{74}$ The Members view committees as having mostly moderate influence on government policy. When asked "How effective do you think the committees of the House are in

\footnotetext{
${ }^{71}$ O'Brien,

${ }^{72}$ White $a$, pp.514-15

${ }^{73}$ Ibid.

${ }^{74}$ Parker, p.63 He notes: "The practice was to hold one session a year in Yellowknife and often the second and third sessions would be held at some other location. We travelled widely, the idea being that it was important for people to see their MLAs in action."
} 
influencing routine or detailed policy questions", $67 \%$ stated moderately effective, with the remaining third stating they were very effective.

\begin{tabular}{|l|c|c|c|c|c|c|c|c|c|}
\hline Table 6 & Number & $\%$ & $\begin{array}{c}\text { White } \\
\%\end{array}$ & Minister & MLA & Aboriginal & $\begin{array}{c}\text { Non- } \\
\text { Aborig. }\end{array}$ & Urban & Rural \\
\hline $\begin{array}{l}\text { Very } \\
\text { effective }\end{array}$ & 5 & $33 \%$ & $46 \%$ & 2 & 3 & 2 & 3 & 3 & 2 \\
\hline $\begin{array}{l}\text { Moderately } \\
\text { Effective }\end{array}$ & 10 & $67 \%$ & $42 \%$ & 4 & 6 & 8 & 2 & 5 & 5 \\
\hline $\begin{array}{l}\text { Not very } \\
\text { effective }\end{array}$ & 0 & $0 \%$ & $13 \%$ & & & & & & \\
\hline
\end{tabular}

For major policy questions, the results were not much different.

\begin{tabular}{|l|c|c|c|c|c|c|c|c|c|}
\hline Table 7 & Number & $\%$ & $\begin{array}{c}\text { White } \\
\%\end{array}$ & Minister & MLA & Aboriginal & $\begin{array}{c}\text { Non- } \\
\text { Aborig. }\end{array}$ & Urban & Rural \\
\hline $\begin{array}{l}\text { Very } \\
\text { effective }\end{array}$ & 4 & $27 \%$ & $42 \%$ & 2 & 2 & 2 & 2 & 2 & 2 \\
\hline $\begin{array}{l}\text { Moderately } \\
\text { Effective }\end{array}$ & 10 & $67 \%$ & $46 \%$ & 3 & 7 & 7 & 3 & 6 & 4 \\
\hline $\begin{array}{l}\text { Not very } \\
\text { effective }\end{array}$ & 1 & $7 \%$ & $13 \%$ & 1 & & 1 & & & 1 \\
\hline
\end{tabular}

The major difference is the drop in support since Professor White's study for the very effective option, although a greater percentage now feels that the committees are at least moderately effective.

With the development of influential committees, Regular Members are much more involved in the legislation development and implementation than elsewhere. Caucus permits in depth discussions on the general direction, vision and goals of the entire Assembly. The Standing Committee on Priorities and Planning, while holding the government accountable in the House, is also able to exert considerable influence through the minority situation endemic to consensus government. 
In the next four chapters, consensus government will be examined in detail through the use of the opinions expressed by its practitioners in the Northwest Territories. The first section deals with accountability, namely how the Legislative Assembly remains accountable to the people of the Northwest Territories whilst employing the consensus model. The next chapter, Transparency, will examine the relationship between the Regular Members and the Executive Council. In Responsiveness, the focus will be on the Legislative Assembly's policy developments and its ability to respond to constituents needs. Finally, Adaptability will argue that consensus government is a Westminster style legislature. 


\section{$\underline{\text { Accountability }}$}

In any democracy, the government must be accountable to the people, in both practice and perception. While this section will argue that consensus government is accountable to the people, the perception exists to the contrary. This may be due in part to the differences that separate consensus from the more familiar partisan legislatures of southern Canada. It is common for these differences to be examined by the media around election time, and not all are favourable towards the status quo. In the weeks leading up to the 1999 election, the first post division, the Inuvik Drum newspaper stated in an editorial, "The consensus system is certainly not perfect. MLAs, like everyone else, possess political and philosophical biases. Motions in the legislative assembly come down to votes in any case and favour the majority. The party system offers openness and accountability -- qualities the assembly is still working to achieve."75 While generally supportive of the consensus system, the editorials of the Yellowknifer newspaper do advocate reform, in the week leading up to the 2000 Territorial Leadership Committee meetings, it was stated, "The latest process for choosing a premier is sad evidence the tradition of backroom wheeling and dealing will persist in the next sitting of the NWT legislative assembly. The charade is so silly that while no one is officially in the running for premier, in fact it is well known who is! What is not known is what the candidates for premier intend to do if successful and more importantly, what do the people of the NWT want their premier to do.,, 76

\footnotetext{
75 Inuvik Drum Editorial, November 19, 1999 "Right to Party" http://www.nnsl.com/frames/newspapers/1999-11/nov19 99edit.html

${ }_{76}$ Yellowknifer Editorial, January 17, 2000, "Backroom Traditions Persist" http://www.nnsl.com/frames/newspapers/2000-01/jan17_00edit.html
} 
Two days following the most recent election, the Slave River Journal out of Fort

Smith argued in an editorial piece,

The premier of the NWT is selected by the members of the Legislative Assembly, after several rounds of serious horse trading, well after the act of electing is over. The 19 members then pick the cabinet. The people have no role in any of that process. How is that democratic? The new premier and cabinet - "The government" - will not have set forth their future vision, will not even identify their priorities and will not have laid out a plan for their intended way things will unfold. In fact, they aren't really required to have a vision or a plan. In the NWT, the government that is manufactured in the legislature later on with no public input will have no enunciated vision and no public plan that it works from, and will be lesser for it. ${ }^{77}$

There may well be a deficit of accountability in the interpretation of consensus government, but does this deficit exist in practice? The most commonly cited failings of the consensus system by those who deride it are the method by which the executive is selected, the lack of clear territorial policy and vision statements during the election period, allegations of backroom politicking, lack of debate over leadership, the lack of an enunciated platform for governance, an inability to hold previous governments accountable after dissolution, and the large number of uncontested ridings in every election. $^{78}$

One way to rectify these problems, according to some, would be to introduce political parties. Indeed, the challenges are such that one prominent scholar who spent some time studying this system, Professor Gurston Dacks of the University of Alberta, once predicted in the early 1990s that consensus government would eventually be overwhelmed by the growing number and complexity of issues it faced. He further

\footnotetext{
${ }^{77}$ Slave River Journal Editorial, October 3, 2007 "Consensus Government not a true Democracy" http://www.sri.ca/default.asp?sourceid=\&smenu=143\&twindow=Default\&mad=No\&sdetail=2262\&wpage $=1 \&$ skeyword $=\&$ sidate $=\& c c a t=\&$ ccatm $=\&$ restate $=$ \&restatus $=$ \&reoption $=$ \& retype $=\&$ repmin $=\&$ repmax $=\& \mathrm{r}$ ebed $=\&$ rebath $=\&$ subname $=\&$ porm $=\& s c=1957 \& h n=$ srj\&he $=$. ca

${ }^{78}$ Since division in 1999, there have been 9 acclamations. One in 1999, five in 2003 and three in 2007.
} 
asserts that "Political parties are still the most efficient way of distributing power and holding legislators to account" ${ }^{79}$ But it will be argued in the following pages that introducing parties into the Legislative Assembly would end consensus-style government.

Most attempts to start a Northern political party, have foundered. Since division, three separate groups have attempted to start a political party. The Western Arctic NDP ran five candidates contending for seats in Yellowknife in 1999, the most successful of whom garnered $20.4 \%$ of the vote and third in the field. ${ }^{80}$ The party ran one candidate unsuccessfully in the next election in 2003, and then appears to have folded. For that same election a group of predominantly Yellowknife business people decided to establish a party, declaring that they were 'fed-up' with consensus government. ${ }^{81}$ However, this group appears to have foundered after its initial meeting. In 2007, one Yellowknife candidate declared himself to be running for the NWT Party, which he had founded. He was likewise unsuccessful, finishing with $3.1 \%$ of the final vote in the riding. ${ }^{82}$

\section{Parties and Seats}

Had two or more party candidates been successful in their bids during one election, they would face a House that has been designed to accommodate individuals and regions. The unique method of Cabinet selection, for example, while ensuring equal representation for the regions, also ensures that no one region can dominate the Standing

\footnotetext{
79 "An election like no other", by Jack Danylchuk Northern News Services, published in News/North newspaper, November 17, 2003 http://www.nnsl.com/frames/newspapers/2003-11/nov17 03elect.html 80 "NDP enter race", by Glen Korstrom, Northern News Services, published in Yellowknifer newspaper, October 29, 1999, http:/www.nnsl.com/frames/newspapers/1999-10/oct29 99ndp.html Results from Official Voting Results 1999, Elections NWT

81 "Group 'fed-up' with consensus" by Jack Danylchuk Northern News Services, published in Yellowknifer newspaper, June 25, 2003, http://www.nnsl.com/frames/newspapers/2003-06/jun25 03pol.html

${ }^{82}$ Website for the NWT Party http://www.nwtparty.com/index.html Results from the 2007 Official Voting Results, Elections NWT
} 
Committee on Priorities and Planning (SCPP). ${ }^{83}$ When presented with the hypothetical situation of a party Member being elected to Cabinet, an official with the NDP stated that "the members are expected to be bound by party policy" 84 , even though that would breach the Westminster tradition of Cabinet solidarity.

Party discipline would have an effect on the Regular Members also. If they were to act, as the NWT Party states, as a 'government in waiting', and oppose Cabinet initiatives in a partisan manner, ${ }^{85}$ the committee structure would undoubtedly be forced to change. In the consensus tradition, committee recommendations are taken seriously by the government, and bills are often amended to meet the recommendations issued in the reports. ${ }^{86}$ With only five Members sitting on each committee, a party with three MLAs could control, or have substantial sway, in two or three committees. In this manner, the self-proclaimed 'government in waiting', even one with a small number of MLAs, would be attempting to alter government policies and legislation. The budget is subjected to the same scrutiny, examined line by line in committee. ${ }^{87}$ The cooperation between Cabinet and the regular Members would suffer if debates over legislation and the budget become partisan. The influence that ordinary Members currently wield would decline as the Cabinet would be less willing to accept committee recommendations. In his study of the attitudes of the MLAs of the eleventh Assembly, Professor White stated

\footnotetext{
${ }^{83}$ The SCPP has 11 Members, after electing 2 Members from each region into Cabinet, the largest remaining region, Yellowknife, has 5 Members.

${ }^{84}$ 'Five Yellowknife candidates will run for MLA under NDP Platform', Northern News Services, October 29, 1999 accessed at http://www.nnsl.com/frames/newspapers/1999-10/oct29 99ndp.html

${ }^{85}$ The Party website states: "It supports an effective opposition to the government that is also an alternative 'government in waiting' to the government. Territorial political organizations involves the public and report on the effectiveness of government in an honest and unbiased way, (unbiased meaning; opposed to, the Government, of the day). [sic] http://www.nwtparty.com/pdf nwtparty/History_One.pdf

${ }^{86}$ Baldwin (page numbers not provided on the online archives) $\sim 8^{\text {th }}$ page

${ }^{87}$ White, $\alpha$, p. 515
} 
The current system is also vulnerable to destabilization. It functions because of an unspoken but clearly understood agreement that MLAs ministers and ordinary members, natives and non-natives, Eastern Arctic and Western Arctic members - will observe certain generally accepted limits. They promote their interests, but without extremism and without attempting to exploit every possible advantage or opportunity, lest compromise and accommodation become impossible. ${ }^{88}$

The introduction of parties into the Legislative Assembly, with the concomitant discipline, would act as a strong destabilizing agent in the consensus style government. Party leaders would seek out opportunities to prove how their leadership would benefit the territory. One party acting alone, especially if it was concentrated in one region, would be able to exploit the many opportunities afforded by the minority government status inherent to consensus.

\section{Parties and Accountability}

It is virtually inconceivable, under party politics, for an individual to become Premier without facing a single voter, as was the case in 2003, when Joe Handley, having been acclaimed in his riding, was subsequently unopposed in his bid for the Premiership. The current Premier, Floyd Roland, has not faced his constituents in an election since 1999. ${ }^{89}$ These examples, under consensus government, can be understood as 'unanimous consent', a phrase employed daily in the Legislative Assembly. One of the virtues of consensus is it enables Members to be able to pick the best possible candidates for leadership roles, as no one is excluded due to partisan reasons. ${ }^{90}$ During her candidacy speech for the Premiership in 1995, Jane Groenewegen stated: "there is a perception by

\footnotetext{
${ }^{88}$ White, $a$, p. $518-19$

${ }^{89}$ In 1999 , Roland defeated two other candidates, garnering over $83 \%$ of the vote. Candidates do have to be nominated by 15 constituents each election. Source: Elections NWT. Roland ran against Michael Miltenberger for the Premiership in 2007.

${ }^{90}$ Dacks, p.352
} 
some that consensus government has failed. They say party politics is needed to set out policy, agenda and bring accountability to the government. An election for Premier allows us to hear from candidates what they hold as priorities, what they stand for and are willing to commit to."91 During the 1991 Territorial Leadership Committee, the Speaker noted at the end of the proceedings that the Government Leader candidates had each faced 79 questions posed by Members. ${ }^{92}$

Government accountability is achieved in consensus government through the ability of the regular Members to install and remove underperforming or objectionable Ministers. The House can revoke by motion the appointment of any Executive Council member at any time. ${ }^{93}$ This is a power that has been exercised in almost every modern Assembly, and has been used to remove a Premier from power, along with many Ministers throughout the past twenty-two years. ${ }^{94}$ The introduction of parties would complicate this process. The primary difficulty is the manner in which MLAs perceive their role. In many ridings, and especially in the predominantly Aboriginal jurisdictions, the Members view themselves as delegates of the people and leadership of that riding. ${ }^{95}$ In the course of the interviews conducted with the Members, several spoke to the importance of regularly seeking advice and opinions from their riding, with one stating "I get a lot of direction from [people in the riding] and a lot of things I decide on for the most part are based on decisions I've heard back home." The importance of consulting

\footnotetext{
${ }^{91}$ Territorial Leadership Committee Hansard, November 20, 1995, p.19

${ }^{92} \mathrm{He}$ then stated that this was more questions than the Prime Minister faced in a year. Territorial Leadership Committee Hansard, November 12, 1991, p.46

${ }^{93}$ Source: Office of the Clerk of the Legislative Assembly of the Northwest Territories

${ }^{94}$ Richard Nerysoo was removed during the no longer used mid-term review, due to what Members perceived as a lack of commitment. Lewis, p.15 Don Morin resigned as Premier after conflict of interest allegations were proven in November 1998.

95 White found that two thirds of Aboriginal MLAs (12/16) viewed themselves as delegates. White, $c$, p.330 Indeed, the small nature of all constituencies leads to "hypersensitivity on the part of members to constituency concerns." White, $c$, p.325
} 
with their constituents is such that, in October of 2006, during the debate on a motion to remove a Minister from Cabinet, the MLA for Sahtu, Norman Yakeleya stated: "I spoke earlier on this issue and am waiting for some feedback from the leadership in the Sahtu region in terms of deciding on a vote here." ${ }^{96}$ This statement highlights the importance that Northern MLAs place on acting according to the wishes of the local leadership in addition to their constituents. It should be noted, however, that even in the smaller ridings with relatively homogenous populations, differences in opinion can vary greatly. Many Members, when asked if they viewed themselves as a trustee or delegate, stated that they were both. They sought advice from their constituents and prominent leaders in the communities, but recognized that when a decision had to be made, they as MLAs had the final vote.

Consensus government has created conventions to keep Ministers accountable to the House, and by extension, to the people the House represents. "While the nonpartisan [sic] system does not provide for collective executive responsibility, it makes the likelihood of the elected members of the executive, individually or collectively, being held accountable by the Assembly greater than is the case when a cabinet commands a majority of votes in a legislature. ${ }^{997}$

\section{$\underline{\text { Parties and Platforms }}$}

Platforms, as they are used in the North, express the individual candidate's plans and visions for the riding. A platform of large policy changes; targeted spending on initiatives; and a territory-wide vision for the future is rare, if not unknown. One or

\footnotetext{
${ }^{96}$ Northwest Territories Hansard, October 19, 2006, p.360. Yakeleya was acclaimed in the 2007 election.

${ }^{97}$ Dacks, p. 352
} 
several candidates adhering to a pre-determined set of goals may impede the consensus system, with its tradition of compromise and accommodation. This is not to say that ideology is absent from Members' positions. Many MLAs have well known connections to federal parties. ${ }^{98}$ Within the Assembly, there are myriad coalitions of ordinary Members based on the position they have taken on any given issue. This is facilitated by the consensus system, which allows each MLA to make a daily 'Member's Statement' on whatever issue they please, followed by 'Oral Questions', where each regular Member raises questions on behalf of their constituents, on issues then before the Assembly or on events in the territory. Furthermore, the time allotted each day for questions or statements can be extended by unanimous consent of the House. The House rarely withholds its consent. ${ }^{99}$ The same holds true for waiving the 48 hour notice required for motions, including motions to revoke appointments to the Executive Council. A visiting clerk from the House of Commons noted "[t]his procedure was so common that members tended to be surprised when unanimous consent was not given."100

The party system would curb this individualism. The party caucus and leader would determine what line of questioning would be pursued on each day. ${ }^{101}$ Unanimous consent could be withheld, which would lead to an acrimonious atmosphere in the House. ${ }^{102}$ The smooth functioning of consensus obliges Members, and especially Cabinet, to allow requests. If consent is withheld, a determined Member can request to

\footnotetext{
${ }^{98}$ One current MLA was the former federal riding chair for the Progressive Conservatives. One Minister has been extensively involved with the Liberals during federal elections, and a former Minister in the last Assembly who declined to run again secured the federal Tory nomination in November 2007.

${ }^{99}$ A quick glance at Hansard from any given day will reveal that Members often overrun their allotted time for statements, and are rarely denied consent to finish their statements.

${ }^{100}$ Baldwin, (page numbers not provided on the online archives) $\sim 7^{\text {th }}$ page

${ }^{101}$ Provided the federal example is followed, where the parties determine who will ask questions. It is possible that the United Kingdom procedure would be used, where the Speaker selects who will speak. ${ }_{102}$ Baldwin noted one day where one Member's requests for consent were consistently denied by one Member. The two men nearly came to blows, necessitating the Sergeant-at-Arms to restore order. Ibid.
} 
return to the Order of Proceedings to persist with their statement, question or motion, thus delaying the business of the House. Furthermore, there is nothing to stop the denied Member from continuing the next day in their statement and oral question. Avoidance is an ill-advised strategy under consensus government.

Consensus government has evolved to avoid the partisanship and rancour associated with 'Southern-style' politics. In a debate over whether the Government Leader should have the power to appoint Ministers to the Executive Council, or if those Ministers should be elected by the House at large, the majority of MLAs spoke against appointments, feeling that it would lead to party politics. ${ }^{103}$ This sentiment has not wavered much in the subsequent years, with $63 \%$ of the Members against the Premier selecting the Executive Council. Titus Allooloo argued "As long as I can I will try to keep the method of the consensus system in the NWT and I too believe it is the best system. I just have to question myself, if we are moving toward party politics, if party politics is better than our system?...I think if we lose the privilege that we enjoy today, we will lose more tomorrow, and we will keep going toward party politics, which to me is not the wishes of my people." 104

\section{$\underline{\text { Parties and the Electoral System }}$}

The NWT Party argue that by electing independents, those who supported losing candidates have lost their voice. Their views are not represented in the Assembly. ${ }^{105}$ Party politics ensures, even if one candidate was defeated, that the views of that

\footnotetext{
${ }^{103}$ Territorial Leadership Committee Hansard, November 12, 1991, pp. 17-21

${ }^{104}$ Ibid. p. 20

${ }^{105}$ The NWT Party Website, http://www.nwtparty.com/pdf_nwtparty/FC_CurrentNWT_PS.pdf and http://www.nwtparty.com/pdf nwtparty/FC PossibleNWT PS.pdf
} 
candidate's supporters can be defended and upheld by the other successful Members of that party. This is debateable, especially in the consensus system. Professor White has noted that "the overwhelming acceptance of single-member plurality is remarkable."106 This could be due in part to the small sizes of the ridings, one MLA stated during the interviews that "I've got 1795 constituents; I should know all of them by their first name." The result is an extraordinary number of acclamations, and electoral victories of landslide proportions. ${ }^{107}$ These results can indicate strong community support in the belief that the candidate is the best person for the job.

The issues facing the Assembly, notably Aboriginal rights, land claims and social issues are relatively unknown in the South. Furthermore, as Dacks states:

Traditional partisan positions do not relate at all clearly to this type of issue [the accommodation of native peoples within the structures of public government]. The principal actors prefer to pursue their goals through organizations which focus directly on these issues, rather than through political parties which would tend to crosscut the issues. Simply put, the people of the NWT are unwilling to apply the brokerage process of Canadian party politics to issues which they deem to be so utterly elemental. ${ }^{108}$

As mentioned previously, electoral support for parties by Northerners during elections is underwhelming. Candidates espousing a party line have a difficult time attracting votes. As such, there is a strong argument to be made that efforts to move towards a party system have been soundly rejected and accountability must be found in within consensus government, rather than in wholesale reform.

\footnotetext{
${ }^{106}$ White, $c$, p.86

${ }^{107}$ In the October 2007 election, 11 of 19 candidates won with over $50 \%$ of the vote. A further 3 were acclaimed. Source CBC online NWT Votes 2007, http://www.cbc.ca/nwtvotes2007/ridings/ Since 1991, there have been 16 acclamations. In only one election, 1995, was the number of people elected with $50 \%$ or more of the vote less than half the House. (11 of 24 Members) Source: Elections NWT.

${ }^{108}$ Dacks, p. 355
} 


\section{$\underline{\text { Members' Perceptions }}$}

The Members of the Legislative Assembly are well aware of the need to hold the government to account, and to be perceived as doing so creditably. The majority agree, to some degree, that the compromises inherent to consensus government render leadership difficult on divisive issues.

\begin{tabular}{|l|c|c|c|c|c|c|c|c|c|}
\hline Table 8 & Number & $\%$ & $\begin{array}{c}\text { White } \\
\%\end{array}$ & Minister & MLA & Aboriginal & $\begin{array}{c}\text { Non- } \\
\text { Aborig. }\end{array}$ & Urban & Rural \\
\hline Strong Agree & 0 & $0 \%$ & $35 \%$ & & & & & & \\
\hline Some. Agree & 10 & $63 \%$ & $39 \%$ & 3 & 7 & 6 & 4 & 6 & 4 \\
\hline Some. Disagree & 4 & $25 \%$ & $9 \%$ & 2 & 2 & 2 & 2 & 2 & 2 \\
\hline Strong Disagree & 2 & $13 \%$ & $17 \%$ & 1 & 1 & 2 & & 1 & 1 \\
\hline
\end{tabular}

Q: The consensus system works well for routine matters of policy, but it doesn't work well at providing leadership on difficult, divisive issues because the government can retain the support of the House and stay in power only through compromises.

Indeed, the majority of Members feel that it is best for the entire group to be able to come to a solution that is acceptable to all, rather than let the leaders decide what is best.

\begin{tabular}{|l|c|c|c|c|c|c|c|c|c|}
\hline Table 9 & Number & $\%$ & $\begin{array}{c}\text { White } \\
\%\end{array}$ & Minister & MLA & Aboriginal & $\begin{array}{c}\text { Non- } \\
\text { Aborig. }\end{array}$ & Urban & Rural \\
\hline Leader & 6 & $40 \%$ & $35 \%$ & 3 & 3 & 3 & 3 & 5 & 1 \\
\hline Group & 9 & $60 \%$ & $65 \%$ & 2 & 7 & 6 & 3 & 4 & 5 \\
\hline
\end{tabular}

Q: If a group was trying to make a decision on an important issue, and had discussed it thoroughly, with everyone having had an opportunity to express a view, but it was unable to agree on what to do, would it be better: For the leaders of the group to decide, using their best judgement OR For the group to keep discussing the question in an attempt to reach a solution that the whole group accepts.

However, this does not prevent the Assembly from tackling difficult issues that are of fundamental importance to the Northwest Territories.

\begin{tabular}{|l|c|c|c|c|c|c|c|c|c|}
\hline Table 10 & Number & $\%$ & $\begin{array}{c}\text { White } \\
\%\end{array}$ & Minister & MLA & Aboriginal & $\begin{array}{c}\text { Non- } \\
\text { Aborig. }\end{array}$ & Urban & Rural \\
\hline Strongly Agree & 1 & $6 \%$ & $17 \%$ & & 1 & & 1 & 1 & \\
\hline Somewhat Agree & 6 & $38 \%$ & $29 \%$ & 2 & 4 & 4 & 2 & 3 & 3 \\
\hline Some. Disagree & 6 & $38 \%$ & $29 \%$ & 3 & 3 & 4 & 2 & 2 & 4 \\
\hline Strongly Disagree & 3 & $19 \%$ & $25 \%$ & 1 & 2 & 2 & 1 & 3 & \\
\hline
\end{tabular}

Q: Members of the Legislature prefer not to debate in the House issues which may be divisive but are of fundamental importance to the NWT (such as land claims, constitutional development, electoral boundaries). 
While the percentage in agreement is not much different than from those expressed twenty years ago, the drop in strong agreement in table 8 is striking. It appears that more MLAs consider consensus government effective, and none believe that it is incapable of leadership on difficult issues. This is complemented by table 9 , which signals that the practitioners of consensus government still feel that compromise is better than swift decisions. This is strengthened by comments made during interviews,

Consensus government is still working well in the Northwest Territories, we do have our challenges. Part of it is there is a need for debate but there's also a need for decision-making to be done. And the longer we take in making these decisions, the more of an impact positive or negative, can happen to the people we represent. ... there are times you almost think consensus government is challenged to make these decisions in a timely fashion so you can get on with business. The simple fact that because it is a consensus government, the fact we do so much more consultation with all members of the assembly, aboriginal organizations, self governments, the business community, each department for example, if they are coming up with a new piece of legislation or policy, they are out there before hand, going out to industry, or for social programs or network groups to get feedback before they formulate the legislative proposal or policy piece. Then we go to Members to do that as well, so there is a lot of consultation that happens. ${ }^{109}$

The length of the process, and the time it requires to come to a consensus, is not indicative of an indecisive legislature or an indictment of backroom politics, instead, it is reflective of the commitment by the Assembly to consult broadly beyond the confines of its own walls. This is not a failure of accountability, rather, it brings government closer to the people it serves.

Come election time, the Assembly, like any other legislature in Canada, is dissolved upon the writ being dropped. Unlike the provincial legislatures, however, every incumbent seeking re-election does so as an independent, and is, at most, identified

\footnotetext{
${ }^{109}$ Member interview.
} 
as one of the 'old guard', and not as a member of the government or opposition. Their campaigns deal primarily with local issues, and the incumbent's ability to bring those issues to the forefront of the House. As such, incumbents have a traditionally high rate of return; since the creation of the western territory, over $80 \%$ of incumbents seeking reelection have been successful. ${ }^{110}$ The majority of Members agree that by working fairly hard and by avoiding serious mistakes or scandals, they are pretty well assured of being re-elected. ${ }^{111}$

This is a source of concern for critics, as they argue that there is no manner by which to hold the previous Assembly accountable, that every incumbent is free to campaign on their individual merits, and not on the record of the Assembly as a whole. When asked, Members are of split opinions as to whether this is a serious flaw of consensus government.

\begin{tabular}{|l|c|c|c|c|c|c|c|c|c|}
\hline Table 11 & Number & $\%$ & $\begin{array}{c}\text { White } \\
\%\end{array}$ & Minister & MLA & Aboriginal & $\begin{array}{c}\text { Non- } \\
\text { Aborig. }\end{array}$ & Urban & Rural \\
\hline Strongly Agree & 3 & $19 \%$ & $33 \%$ & & 3 & 1 & 2 & 2 & 1 \\
\hline Somewhat Agree & 5 & $31 \%$ & $25 \%$ & 2 & 3 & 4 & 1 & 2 & 3 \\
\hline Some. Disagree & 4 & $25 \%$ & $16 \%$ & 2 & 2 & 2 & 2 & 2 & 2 \\
\hline Strongly Disagree & 4 & $25 \%$ & $25 \%$ & 2 & 2 & 3 & 1 & 3 & 1 \\
\hline
\end{tabular}

Q: The voters in each riding can only pass judgement on the record and the abilities of the local MLA; they have no opportunity to pass judgement on the record and the abilities of the Cabinet. This is a serious flaw in our political system.

The split over whether this constitutes a serious problem in consensus government may be due to the perception of the MLAs roles in the Assembly. The small population in every riding allow the MLAs to be highly visible and accessible to their constituents.

\footnotetext{
${ }^{110}$ Since the election in December 1999, 42 MLAs have sought re-election. 34 were successfully re-elected or acclaimed, or a re-election rate of $80.95 \%$.

${ }^{111} 67 \%$ of MLAs agreed strongly or somewhat with the statement: As long as an MLA works fairly hard and avoids serious mistakes or scandals, he or she is pretty well assured of being re-elected. This percentage is equal to that found by White twenty years previous.
} 
Caucus allows each MLA an opportunity to speak to government initiatives and priorities, and to have genuine influence in setting policy. One Member stated:

The strategic planning session was very interesting to me, that was 19 people, that wasn't Ministers and that wasn't Regular MLAs, that was 19 individuals who have thoughts and wishes of their constituents on their mind when they're trying to come up with a strategic plan, and all of us, in my opinion, I was heard, I had the opportunity to stand up and say things that were important to my riding and to my constituents, but also talk about the North as a whole. I think the greatest strength is that, our ability to, as an individual, to have an impact.

Furthermore, the accessibility of MLAs enables constituents to voice their concerns directly to their representative; several Members mentioned how their constituents will stop them as they do their shopping or at the gas pumps to express their displeasure over government decisions or to offer alternatives. All Members are identified as the government, regardless of whether they sit on the Executive Council or not. Under consensus government, that assessment is not entirely inaccurate.

Unlike partisan legislatures, the electorate is not given the choice between competing platforms, instead, they are asked to choose the individual they feel would best be able to bring their concerns and issues to the table. Unlike the south, there are two forums in which to do this, the first being the House, the second being Caucus. It is in Caucus that the Strategic Plan is decided upon, and it is in the House that the Executive Council is scrutinized on their efforts to bring that plan to fruition. While it is the Executive that is responsible for bring forward the legislation and direction, all Members are party to its inception. Furthermore, it is up to the Members to ensure that the Cabinet remains committed to the ideals set forth in the Strategic Plan. As such, a substantial majority of the Members, including every Regular Member, agree that the Standing Committee on Priorities and Planning should be more cohesive. 


\begin{tabular}{|l|c|c|c|c|c|c|c|c|c|}
\hline Table 12 & Number & $\%$ & $\begin{array}{c}\text { White } \\
\%\end{array}$ & Minister & MLA & Aboriginal & $\begin{array}{c}\text { Non- } \\
\text { Aborig. }\end{array}$ & Urban & Rural \\
\hline Strongly Agree & 5 & $33 \%$ & $54 \%$ & & 5 & 2 & 3 & 4 & 1 \\
\hline Somewhat Agree & 9 & $60 \%$ & $25 \%$ & 4 & 5 & 6 & 3 & 4 & 5 \\
\hline Some. Disagree & 1 & $7 \%$ & $17 \%$ & 1 & & 1 & & & 1 \\
\hline Strongly Disagree & 0 & $0 \%$ & $4 \%$ & & & & & & \\
\hline
\end{tabular}

Q: The Regular Members should stick together more so that they can put more pressure on the government.

One reason for the strong results here may be due to the perception that the Regular Members are generally too disorganized to effectively force the Cabinet to change a decision.

\begin{tabular}{|l|c|c|c|c|c|c|c|c|c|}
\hline Table 13 & Number & $\%$ & $\begin{array}{c}\text { White } \\
\%\end{array}$ & Minister & MLA & Aboriginal & $\begin{array}{c}\text { Non- } \\
\text { Aborig. }\end{array}$ & Urban & Rural \\
\hline Strongly Agree & 1 & $7 \%$ & $21 \%$ & & 1 & 1 & & & 1 \\
\hline Somewhat Agree & 9 & $60 \%$ & $33 \%$ & 4 & 5 & 5 & 4 & 5 & 4 \\
\hline Some. Disagree & 4 & $27 \%$ & $21 \%$ & 2 & 2 & 3 & 1 & 2 & 2 \\
\hline Strongly Disagree & 1 & $7 \%$ & $25 \%$ & & 1 & 1 & & 1 & \\
\hline
\end{tabular}

Q: Even though the Regular Members outnumber the Cabinet, they are usually too disorganized or too divided among themselves to be able to make the Cabinet change its mind.

These results represent a serious challenge to the effectiveness of consensus government, and also constitute a question of accountability. They reveal a worrying aspect of consensus government: that the Regular Members are unable or unwilling to hold the Executive to account. If the former is true, there exists a fundamental flaw in the institution. If it is the latter, it could pose an even greater threat to responsible government in the Northwest Territories.

Members of the Executive Council hold office with the consent of the House. Only the House may elect or remove Members, and this power has been exercised in every Assembly since division. Motions of censure have been passed on Premiers, and Cabinet. However, as one editorial argues, this power is not always used judiciously.

So-called ordinary MLAs [fired] Health and Environment Minister Michael Miltenberger because he showed a lack of respect for an MLA. 
Our question is: Why do MLAs only exercise the power given them by the voters when they are insulted?

These same MLAs allow important questions to cabinet colleagues to go unanswered. They allow themselves to be spoon-fed government information on condition they do not share the information with the public. They complain when cabinet acts contrary to what most MLAs want but MLAs do nothing about it....

But MLAs have confused the power structure of traditional parliamentary government with consensus government. Cabinet supremacy works fine with party politics. It doesn't work at all with consensus...MLAs are the boss but they are not treated as such. ${ }^{112}$

When asked who they thought kept the government accountable, the majority of Members stated that it was the responsibility of the Regular Members to do so. As one Member put it, "Some people say the Regular MLAs form the official opposition, I'm not sure I agree with that terminology or concept, we're all one government, we as Regular Members are responsible for accountability and oversight, we are responsible for ensuring that the government is doing what it is saying it is doing, but also bringing new concepts and ideas and if we see something going wildly off the tracks, it's our obligation to identify that." There are accountability mechanisms in place; indeed, the government would have an extremely difficult time in attempting to force an unpopular measure through the House, especially since the Regular Members cannot be browbeaten into accepting it with the threat of an election. If anything, it is those Members on the Executive Council who stand to lose their positions as Ministers if they risk the displeasure of the Regular Members. However, this brings up a paradox within consensus government, namely, that the government is only as accountable as the Regular Members are willing to make it. The lack of will in Regular Members to punish

\footnotetext{
${ }^{112}$ News/North Editorial, "Who's the Boss?", October, 23, 2006, http://www.nnsl.com/frames/newspapers/2006-10/oct23 06edit.html
} 
transgressions that undermine their influence or input in consensus government results in less accountability, substantially so if the Executive then begins to withhold vital information. One proposed solution, however, creates several new difficulties.

\section{Direct Election of the Premier}

In the last sitting of the fifteenth Assembly, a Yellowknife MLA made a Member's Statement arguing in favour of having the people directly elect the Premier. ${ }^{113}$ This was met with many inaudible interjections by other Members, uncommon to the consensus system, where the tradition is to listen with respectful silence. ${ }^{114}$ He argued that a directly elected Premier would have a clear mandate from across the territory, would have the strength to pick Ministers to form "an A-team, our star team." The Premier's power to choose Ministers would grant the office "the ultimate authority" to ensure Ministerial performance. "It should not be up to Regular Members to spill blood in the Assembly for the Premier when he should be doing his job."

This is not a new proposal. During a debate over whether Ministers should be appointed or elected, several Members argued that until such a time as the Premier is elected by all Northerners, Cabinet should be elected by the House. ${ }^{116}$ As the government of Nunavut was being developed, "the designers...contemplated grafting a popularly elected premier onto the consensus system. Creating strong, accountable leadership in this way was mooted as a means of overcoming the failings of the

\footnotetext{
${ }^{113}$ Robert Hawkins' Member Statement, Northwest Territories Hansard, August 17, 2007, p.383

114 The civility of debate in the House is often cited, notably in works by Professor White. See White, $c$, p.84; White, $b$, p.327.

${ }_{116}$ All quotes from Hawkins' Member Statement, Northwest Territories Hansard, August 17, 2007, p.383

${ }^{116}$ This position was argued best by Fred Koe, "I feel that until the Government Leader is elected by all the people of the Northwest Territories, I cannot support giving that individual the power and authority at this time to choose a cabinet." Several other Members expressed similar sentiments. Territorial Leadership Committee Hansard, November 12, 1991, pp.18-20
} 
consensus system." 117 In his last days in office, then Premier Stephen Kakfwi argued in favour of a Premier elected at large, citing greater stability and less backroom politics. Cabinet, he said, "could still be chosen by MLAs to give them some say in the executive." He continued by stating "The only thing the MLAs won't be able to do any more is threaten the premier. If there was a deadlock, we're the experts on compromise and consensus. If it came to a crisis, there would have to be a general election. Everybody would be interested [in] reaching [an] agreement." ${ }^{118}$ However, as White notes, this "would fundamentally alter the ... political system since a popularly elected first minister is essentially incompatible with the basic tenets of Westminster-style responsible government." 119

There are further concerns relating directly to consensus government. In addition to the popularly elected mandate of the Premier versus the mandate of the MLAs, that this reform entails, it undermines the consensual nature the House operates under. Any amendments proposed in committee to legislation favoured by the Premier could be subject to deadlock in the House. Whereas currently the government often accepts amendments, due in part to the community consultations the committee undertakes, a popularly elected Premier could argue that he or she has a mandate from the people, and should not be subject to special interests. The solution proposed to the deadlock, a general election, eliminates the ability of the legislature to hold the Premier accountable to the House.

\footnotetext{
${ }^{117}$ White, $c$, p. 85

${ }^{118}$ Northern News Services, "Voters must pick Premier: Kakfwi", November 26, 2003, accessed at http://www.nnsl.com/frames/newspapers/2003-11/nov26_03kak.html

${ }^{119}$ White, $c$, p.86
} 
Perhaps the greatest threat to consensus government, under this proposal, is found entirely outside of the Legislature. The costs of mounting a territory wide campaign by one person would be astronomical. There are over twenty thousand voters scattered in thirty-three communities across 1.1 million square kilometres. The City of Yellowknife accounts for just fewer than $44 \%$ of the registered voters. Nearly $68 \%$ of all voters live in the three largest communities. ${ }^{120}$ Even if the Elections Act were to be amended to increase the amount of donations one candidate may receive, ${ }^{121}$ the outlay required for a candidate to be visible in every riding would be prohibitive, especially given that many communities are inaccessible by land. ${ }^{122}$ Two scenarios emerge from this situation. The first is political domination of the executive office by the urban centres, as candidates from the smaller communities are marginalized. It is likely that most candidates would not campaign in every community due to cost. The second is the emergence of parties. Whether these are cohesive political machines or less formal coalitions, the end result is a strong likelihood of parties dominating the Legislative Assembly.

The consensus system achieves accountability through the Regular Members holding the Executive Council to account. It is, in fact, the responsibility of numerically superior regular Members to "keep Ministers in line". ${ }^{123}$ Under the consensus system, all authority flows from the consent of the House, Ministers serve at the pleasure of regular Members, who can remove them by simple majority. A directly elected Premier would alter this balance drastically. By removing the selection of Premier from the consent of

\footnotetext{
${ }^{120}$ Yellowknife, Hay River and Inuvik. Elector numbers provided by Elections NWT.

${ }^{121}$ Currently set at $\$ 30,000$ in cash, property or services. This is also the maximum allowable amount that can be spent on a campaign. Source: Elections NWT

${ }^{122}$ Furthermore, the road access to the communities in the Mackenzie Delta in the north is via a circuitous route through British Columbia and the Yukon.

${ }^{123}$ Robert Hawkins Member Statement, Northwest Territories Hansard, August 17, 2007 p.383
} 
Members, and therefore the House, accountability for executive actions shifts directly to the people. For Members who see themselves as delegates for their riding, they would be unable to act on any discontent voiced by their constituents about the leadership of the territory. The Premier would not be serving at the pleasure, and with the consent, of the House, a founding principle of consensus government.

It is clear that the greatest measure of accountability within consensus government is the transparency of government plans, with so much information shared between the Executive and the Regular Members. The access to privileged information that the Regular Members enjoy is unparalleled in southern Canadian legislatures. The influence of the committees to propose amendments is such that it led a Special Committee examining the rules, privileges and procedures of the Legislative Assembly to state: "[i]n a sense then, the Assembly as a whole acts as an Upper House in respect of legislation while the Legislative Committee acts as a Lower House." 124 These tenets are essential to the smooth functioning of consensus government, and are central to its capacity to ensure responsible government to the people of the Northwest Territories.

\footnotetext{
${ }^{124}$ Third Report of the Special Committee on Rules, Procedures and Privileges, $10^{\text {th }}$ Assembly, Ted Richard, Chairman. Quote on p. 14
} 


\section{Transparency}

In his report on the Commission of Inquiry into the Sponsorship Program and Advertising Activities, Justice John Gomery stated "Transparency promotes accountability and better management." ${ }^{.25}$ He elaborated further in his final recommendations,

Rebalancing the relationship between Parliament and the Government would enable the House of Commons to hold the Government, individual Ministers and their departments to account and to review more effectively the Government's proposed spending plans. In assigning accountability more clearly, there is greater likelihood that officials at all levels will assume their responsibilities more fully and, in so doing, reduce the risk of mismanagement and scandals. Canadians will also be able to identify more readily who is responsible and for what. ${ }^{126}$

Under consensus government, one of the primary roles of the Regular Members is to keep the Executive accountable. One method employed in this task is the use of committees, through which the Regular Members gain access to government plans, departmental spending and legislative proposals. While the majority agree that the Standing Committee on Priorities and Planning does fulfill the same niche as opposition parties in partisan legislatures in the House, the same percentage also agrees that the views of the Regular Members are considered carefully by the government.

\begin{tabular}{|l|c|c|c|c|c|c|c|c|c|}
\hline Table 14 & Number & $\%$ & $\begin{array}{c}\text { White } \\
\%\end{array}$ & Minister & MLA & Aboriginal & $\begin{array}{c}\text { Non- } \\
\text { Aborig. }\end{array}$ & Urban & Rural \\
\hline Strongly Agree & 2 & $13 \%$ & $16 \%$ & & 2 & 2 & & 1 & 1 \\
\hline Somewhat Agree & 11 & $69 \%$ & $33 \%$ & 5 & 6 & 7 & 4 & 6 & 5 \\
\hline Some. Disagree & 1 & $6 \%$ & $33 \%$ & & 1 & & 1 & 1 & \\
\hline Strongly Disagree & 2 & $13 \%$ & $16 \%$ & 1 & 1 & 1 & 1 & 1 & 1 \\
\hline
\end{tabular}

${ }^{125}$ Justice John Gomery, "Restoring Accountability: Report of the Commission of Inquiry into the Sponsorship Program and Advertising Activities", Government of Canada, 2006, p.177, chap. 10 accessed at http://epe.lac-bac.gc.ca/100/200/301/pco-bcp/commissions-ef/sponsorship programef/phase2report/en/phase2report/recommendations/default.htm

126 Ibid, pp. 198-199 
Q: The Standing Committee on Priorities and Planning does pretty much what an opposition does in other Canadian legislatures.

\begin{tabular}{|l|c|c|c|c|c|c|c|c|c|}
\hline Table 15 & Number & $\%$ & $\begin{array}{c}\text { White } \\
\%\end{array}$ & Minister & MLA & Aboriginal & $\begin{array}{c}\text { Non- } \\
\text { Aborig. }\end{array}$ & Urban & Rural \\
\hline Strongly Agree & 7 & $44 \%$ & $33 \%$ & 4 & 3 & 5 & 2 & 4 & 3 \\
\hline Somewhat Agree & 6 & $38 \%$ & $42 \%$ & 2 & 4 & 4 & 2 & 3 & 3 \\
\hline Some. Disagree & 3 & $19 \%$ & $25 \%$ & & 3 & 1 & 2 & 2 & 1 \\
\hline Strongly Disagree & 0 & $0 \%$ & $0 \%$ & & & & & & \\
\hline
\end{tabular}

Q: Generally speaking, the views of Regular Members are considered very seriously by the government.

These two findings would, in all likelihood, be considered mutually exclusive in Parliament or provincial legislatures. Under consensus government, however, it is vital to the smooth functioning of the Assembly that the Regular Members be able to not only express their views and opinions, but to have those same considered seriously by the Executive.

This relationship is further exhibited when the Regular Members were asked if they were satisfied with their ability to influence government policy in their respective ridings and for the territory as a whole. The results are strongly in the affirmative, with $90 \%$ being satisfied on riding specific issues, and $80 \%$ for the territory as a whole.

Table 16

\begin{tabular}{|l|c|c|c|c|c|c|c|}
\hline Riding & Number & $\%$ & $\begin{array}{c}\text { White } \\
\%\end{array}$ & NWT & Number & $\%$ & $\begin{array}{c}\text { White } \\
\%\end{array}$ \\
\hline $\begin{array}{l}\text { Strongly } \\
\text { Agree }\end{array}$ & 3 & $30 \%$ & $18 \%$ & & 2 & $20 \%$ & $29 \%$ \\
\hline $\begin{array}{l}\text { Somewhat } \\
\text { Agree }\end{array}$ & 6 & $60 \%$ & $41 \%$ & & 6 & $60 \%$ & $53 \%$ \\
\hline $\begin{array}{l}\text { Some. } \\
\text { Disagree }\end{array}$ & 1 & $10 \%$ & $29 \%$ & & 2 & $20 \%$ & $11 \%$ \\
\hline $\begin{array}{l}\text { Strongly } \\
\text { Disagree }\end{array}$ & 0 & $0 \%$ & $12 \%$ & & 0 & $0 \%$ & $6 \%$ \\
\hline
\end{tabular}

Q: On issues that affect only my riding, Q: On issues of importance to the entire NWT, I am satisfied with my ability to influence government policy.

Thus despite fulfilling a similar role to the opposition parties elsewhere, Regular Members do wield power over government policies in a tangible and constructive 
manner. Instead of having to oppose a policy or bill, Members are given the opportunity to suggest amendments, which the Executive considers seriously, and, according to the Members, they are satisfied with the attention the Executive pays to their concerns and amendments.

Through Caucus and the committees, the Executive seeks to ensure that it remains accountable to the Regular Members, the House and thereby, the people of the Northwest Territories. During interviews, several Members commented on the importance of this sharing of information. One stated:

The greatest strength to me is the fact that we work together, we share a lot more information with all members then we would in any other system of government. For example, we get to see the budget plans before they are tabled in the house, so you can have some input there, you see legislative proposals [and] you have a comment on that, then you see the bills themselves as a Regular Member, and you can take them out and get public input on those and then again in the house in a more formal way. So it is in fact as a Regular Member [that] you do have influence on the government.

Another Member said "sometimes it's easy to overlook the fact that you actually are being privy to an awful lot of information that in other types of government's you wouldn't see. So it is always a balance of trying to keep government being open and accountable to the Members making sure that they get all the information they need to make the decision." The flow of information from the Executive to the Regular Members is essential, and when the Members feel that they are being kept intentionally uninformed, mistrust can develop, the Executive may, as alleged in an editorial mentioned previously ${ }^{127}$, think itself more important than the Regular Members, and hold them in contempt.

\footnotetext{
${ }^{127}$ News/North Editorial, "Who's the Boss?", October, 23, 2006, http://www.nnsl.com/frames/newspapers/2006-10/oct23 06edit.html
} 
Given the degree of influence the Regular Members hold, it is interesting to note some divisions in opinion. The Members are split on whether it would be practical for the Regular Members to have more influence on the government.

\begin{tabular}{|l|c|c|c|c|c|c|c|c|c|}
\hline Table 17 & Number & $\%$ & $\begin{array}{c}\text { White } \\
\%\end{array}$ & Minister & MLA & Aboriginal & $\begin{array}{c}\text { Non- } \\
\text { Aborig. }\end{array}$ & Urban & Rural \\
\hline Strong Agree & 1 & $6 \%$ & $25 \%$ & 1 & & 1 & & & 1 \\
\hline Some. Agree & 7 & $44 \%$ & $33 \%$ & 1 & 6 & 3 & 4 & 5 & 2 \\
\hline Some. Disagree & 7 & $44 \%$ & $9 \%$ & 4 & 3 & 6 & 1 & 3 & 4 \\
\hline Strong Disagree & 1 & $6 \%$ & $33 \%$ & & 1 & & 1 & 1 & \\
\hline
\end{tabular}

Q: It would not be practical for Regular Members to have more direct influence in running the government than they do now.

Ministers are more likely to feel that the Regular Members could have more influence, whilst a small majority of Regular Members feel that having more influence would not be practical. Some possibilities for this result may include that Regular Members are inclined to feel overworked with committee meetings, constituency work and House sittings. Alternatively, it may be felt that they already exercise significant influence through the committees and Caucus, and that any more influence could result in less accountability if the boundary between the Executive and the Regular Members became distorted.

A significant majority feel that the balance of power between the Executive and the Regular Members has remained consistent over the past few years.

\begin{tabular}{|l|c|c|c|c|c|c|c|c|c|}
\hline Table 18 & Number & $\%$ & $\begin{array}{c}\text { White } \\
\%\end{array}$ & Minister & MLA & Aboriginal & $\begin{array}{c}\text { Non- } \\
\text { Aborig. }\end{array}$ & Urban & Rural \\
\hline Cabinet power & 2 & $13 \%$ & $25 \%$ & & 2 & & 2 & 2 & \\
\hline Balance & 13 & $81 \%$ & $46 \%$ & 5 & 8 & 9 & 4 & 6 & 7 \\
\hline Members Power & 1 & $6 \%$ & $29 \%$ & 1 & & 1 & & 1 & \\
\hline
\end{tabular}

Q: Over the past few years, would you say: A. The Cabinet has been gaining power at the expense of the Regular Members, B. The balance between the Regular Members and the Cabinet hasn't changed very much or C. The Regular Members have been gaining power at the expense of the Cabinet.

While one Minister felt the Executive had lost power to the Members, and two Members felt the Cabinet had gained power at their expense, the majority in every demographic felt 
that a balance had been maintained. The ability of the Regular Members to unseat a Minister, and the exercising of that power in the past few Assemblies, is a probable cause for this result. As one Member said, "every Minister is reviewed every day they are in the house and if concerns warranted it, they would be gone in two days. And that goes for the Premier too. All you need is 48 hours for a motion to move through."

The ability of the Regular Members to remove a Minister at will is one of the most unique facets of consensus government. Not only must the government maintain the confidence of the House, it must also retain the Members' consent to be governed by those individuals elected to the Executive. In the debate over a motion to remove a Minister, one Member stated "I guess the hardest thing for me is to stand up here and be judge and jury of one of my peers, one of my colleagues. However, when you enter this forum and this level of politics, there is no other place to go for somebody to pass judgment. That judgment has to be made by ourselves." 128 Speaking to the same motion, Floyd Roland said "If Members cannot trust a Minister when he's responding to questions or information being provided and always second guessing and wondering if that is true, that does a lot of damage for our system and the way we operate." ${ }^{129}$ It is evident that a revocation of appointment to the Executive Council is not considered lightly, and is often accompanied by extensive speeches in both support and opposition.

As such, it is not surprising that Members are split on the following question: In theory, the Regular Members have power over the government because of their ability to vote it out of office, but in reality it is extremely unlikely that Members would bring down a government, since doing so would create a chaotic situation.

\footnotetext{
${ }^{128}$ Michael McLeod, Northwest Territories Hansard, May 31, 2004, p.634

${ }^{129}$ Ibid, p.636
} 


\begin{tabular}{|l|c|c|c|c|c|c|c|c|c|}
\hline Table 19 & Number & $\%$ & $\begin{array}{c}\text { White } \\
\%\end{array}$ & Minister & MLA & Aboriginal & $\begin{array}{c}\text { Non- } \\
\text { Aborig. }\end{array}$ & Urban & Rural \\
\hline Strongly Agree & 4 & $25 \%$ & $25 \%$ & 1 & 3 & 1 & 3 & 3 & 1 \\
\hline Somewhat Agree & 4 & $25 \%$ & $38 \%$ & 1 & 3 & 4 & & & 4 \\
\hline Some. Disagree & 6 & $38 \%$ & $17 \%$ & 3 & 3 & 3 & 3 & 4 & 2 \\
\hline Strongly Disagree & 2 & $13 \%$ & $21 \%$ & 1 & 1 & 2 & & 2 & \\
\hline
\end{tabular}

N.B. Numbers don't add up exactly due to rounding.

While Ministers are more inclined to believe Members would bring down the government, other results are less apparent. Aboriginal Members are split, as are NonAboriginal Members. Urban Members are more likely to believe the government could fall than those from smaller communities. A greater percentage now believes that Members would bring down the government than under Professor White's study. This may be evidence of greater confidence in the system, perhaps due to the experience in removing Ministers in the Assemblies since division. Members may also be stating that removing the entire government would not create a chaotic situation.

Consensus government allows the Members to select the Executive Council, and as such, the removal of that Council by the House would not precipitate an election. The House would immediately recess, and reconvene as the Territorial Leadership Committee, and new elections would be held for the Premiership and Ministerial positions, following the agreed upon convention of regional seats on the Executive Council. There is, however, no impediment to the recently removed Ministers from putting their names forward once more.

One possible cause for the Regular Members to seek a total recall of the Executive Council would be a complete loss of trust between the two sides of the House. This could occur in several ways, with the Executive acting with disdain for the Regular Members, or bribing two Members for their support, in exchange for services for those 
Members' ridings. Fortunately, neither of these appears to be the case currently. The majority replied "not very often when asked "How often does it happen that MLAs agree to support government policies in return for having the government direct services or funding to the MLAs' constituencies?"

\begin{tabular}{|l|c|c|c|c|c|c|c|c|c|}
\hline Table 20 & Number & $\%$ & $\begin{array}{c}\text { White } \\
\%\end{array}$ & Minister & MLA & Aboriginal & $\begin{array}{c}\text { Non- } \\
\text { Aborig. }\end{array}$ & Urban & Rural \\
\hline Never & 3 & $21 \%$ & $33 \%$ & & 3 & 2 & 1 & 2 & 1 \\
\hline Not very often & 9 & $64 \%$ & $21 \%$ & 6 & 3 & 7 & 2 & 4 & 5 \\
\hline Now and then & 2 & $14 \%$ & $38 \%$ & & 2 & 1 & 1 & 1 & 1 \\
\hline All the time & 0 & $0 \%$ & $8 \%$ & & & & & & \\
\hline
\end{tabular}

These results show a significant drop in the perceived frequency of such support from twenty years ago. This may be due to increased sensitivity to the perception of back room politics, a greater sense of solidarity among the Regular Members, or reluctance on the part of the Executive to use such tactics.

When it comes to the motions and proposals of the Regular Members, however, there is a strong belief that Members offer support more often to gain support for their own projects.

\begin{tabular}{|l|c|c|c|c|c|c|c|c|c|}
\hline Table 21 & Number & $\%$ & $\begin{array}{c}\text { White } \\
\%\end{array}$ & Minister & MLA & Aboriginal & $\begin{array}{c}\text { Non- } \\
\text { Aborig. }\end{array}$ & Urban & Rural \\
\hline Not very often & 4 & $25 \%$ & $63 \%$ & 1 & 3 & 3 & 1 & 3 & 1 \\
\hline Fairly often & 12 & $75 \%$ & $33 \%$ & 5 & 7 & 7 & 5 & 6 & 6 \\
\hline All the time & 0 & $0 \%$ & $4 \%$ & & & & & & \\
\hline
\end{tabular}

Q: Sometimes when MLAs support other MLAs' motions or proposals, it is not because they're good ideas but because by doing so they will gain support for their own projects. How often does this happen?

This result may be indicative of the backroom politics that is so often criticised. It is essential to build coalitions, especially among the Regular Members, to pass motions in the House. Voting for a colleague's motion is one way to build support provided that person feels indebted. However, this represents a worrisome trend. A greater number of 
Members now feel that this is a regular occurrence, as opposed to the early years. If Members find this to be the most effective way of garnering support, it begs the question of where is the due diligence when deciding to support an initiative or legislation. Northerners would be within their rights to question if their representative is voting for or against a measure not on its merits but in the expectation of future support.

One Member referred to the government as "made up of 19 little governments because you're an independent speaking for your own community, your own constituents, and members hold very highly the right that they have to speak on behalf of their constituents and the people that elected them." With a government composed of 19 independents, perhaps it is not surprising to find that the majority feel that raising an issue in the House is not the more effective way to get the government to act.

\begin{tabular}{|l|c|c|c|c|c|c|c|c|c|}
\hline Table 22 & Number & $\%$ & $\begin{array}{c}\text { White } \\
\%\end{array}$ & Minister & MLA & Aboriginal & $\begin{array}{c}\text { Non- } \\
\text { Aborig. }\end{array}$ & Urban & Rural \\
\hline Strong Agree & 1 & $7 \%$ & $29 \%$ & & 1 & 1 & & & 1 \\
\hline Some. Agree & 4 & $27 \%$ & $38 \%$ & 2 & 2 & 4 & & 2 & 2 \\
\hline Some. Disagree & 8 & $53 \%$ & $21 \%$ & 3 & 5 & 4 & 4 & 5 & 3 \\
\hline Strong Disagree & 2 & $13 \%$ & $13 \%$ & 1 & 1 & 1 & 1 & 1 & 1 \\
\hline
\end{tabular}

Q: Raising an issue publicly in the House is a more effective way of getting the government to act on it than trying to resolve it behind the scenes.

Whereas twenty years ago, two thirds of the Members felt that the House was more effective, now almost the same percentage disagrees, stating that resolving it outside of the House is more productive. While at first glance this would tend to support the allegation that backroom politics are endemic to consensus government, it is important to note that convincing the government to take action is not the same as holding the government to account. Given the small nature of the riding populations, and the approachability of the Members to their constituents, many of the matters resolved 
outside of the House may be of a personal nature, dealing with student loans, healthcare, pensions or hunting and trapping permits.

However, $69 \%$ of the Members did agree that too many of the important decisions made by the Legislature are made outside of the public eye, in Committee or Cabinet.

\begin{tabular}{|l|c|c|c|c|c|c|c|c|c|}
\hline Table 23 & Number & $\%$ & $\begin{array}{c}\text { White } \\
\%\end{array}$ & Minister & MLA & Aboriginal & $\begin{array}{c}\text { Non- } \\
\text { Aborig. }\end{array}$ & Urban & Rural \\
\hline Strong Agree & 1 & $6 \%$ & $33 \%$ & & 1 & & 1 & 1 & \\
\hline Some. Agree & 10 & $63 \%$ & $33 \%$ & 3 & 7 & 7 & 3 & 5 & 5 \\
\hline Some. Disagree & 5 & $31 \%$ & $21 \%$ & 3 & 2 & 3 & 2 & 3 & 2 \\
\hline Strong Disagree & 0 & $0 \%$ & $13 \%$ & & & & & & \\
\hline
\end{tabular}

Q: Too many of the important decisions made by the Legislature are really settled in private; these things should be decided more openly so that the public knows what's going on.

This percentage is similar to that of twenty years ago, indicating that little progress has been made in having the important debates in the House, rather than in the Caucus or Committee rooms. However, once again, more MLAs are in the somewhat agree category, with a substantial drop of support for the strongly agree option. These decisions might include what to prioritize in the Strategic Plan, the land claims process, and devolution. It also highlights that while Caucus and Committees are essential to the smooth functioning of consensus government, they can be viewed as secretive and unaccountable forums, and thereby construed as undemocratic. While this is a false assumption given the role they play, ${ }^{130}$ it is obvious that further efforts are required by the Assembly to have the debates on issues of territorial importance in the House.

A further issue that needs to be dealt with is the perception of the power wielded by the bureaucracy. The civil service is the pre-eminent employer in the Northwest Territories, ${ }^{131}$ and is largely centred in Yellowknife, which is itself a source of concern for many MLAs. One Member stated "the bureaucracy has way too much power. It is

\footnotetext{
${ }^{130}$ See the chapter on Procedure, especially the Caucus subsection, p. 28 and Committee subsection, p.30

${ }^{131}$ Employing over 4,000 people, or more than $10 \%$ of the total workforce.
} 
like the party never changes so the people next to the ministers are the most constant positions in the government...it is entrenched and because there is no party politics that means no party comes in with their own deputy ministers, the positions are entrenched and it is very difficult to make changes." Another made the comment that "I think there are some accountability issues, I think often that in this particular reality, the tail wags the dog where the politicians are the dog and the tail is the bureaucrats." This belief is reflected with a majority of the Regular Members stating that the Ministers pay more attention to their civil servants than they do to the MLAs.

\begin{tabular}{|l|c|c|c|c|c|c|c|c|c|}
\hline Table 24 & Number & $\%$ & $\begin{array}{c}\text { White } \\
\%\end{array}$ & Minister & MLA & Aboriginal & $\begin{array}{c}\text { Non- } \\
\text { Aborig }\end{array}$ & Urban & Rural \\
\hline Strong Agree & 3 & $19 \%$ & $33 \%$ & & 3 & 3 & & 1 & 2 \\
\hline Some. Agree & 5 & $31 \%$ & $29 \%$ & & 5 & 1 & 4 & 4 & 1 \\
\hline Some. Disagree & 4 & $25 \%$ & $17 \%$ & 2 & 2 & 2 & 2 & 2 & 2 \\
\hline Strong Disagree & 4 & $25 \%$ & $21 \%$ & 4 & & 4 & & 2 & 2 \\
\hline
\end{tabular}

Q: Ministers pay more attention to their civil servants than to MLAs.

While every Minister disagreed, it is worrying that the majority of Regular Members feel that the bureaucracy has greater sway with the Ministers than they do themselves.

A further trend that will have to be addressed is the perception among Regular Members that the constituencies of Ministers receive better services than their own.

\begin{tabular}{|l|c|c|c|c|c|c|c|c|c|}
\hline Table 25 & Number & $\%$ & $\begin{array}{c}\text { White } \\
\%\end{array}$ & Minister & MLA & Aboriginal & $\begin{array}{c}\text { Non- } \\
\text { Aborig. }\end{array}$ & Urban & Rural \\
\hline Strong Agree & 1 & $6 \%$ & $29 \%$ & & 1 & 1 & & & 1 \\
\hline Some. Agree & 8 & $50 \%$ & $29 \%$ & & 8 & 3 & 5 & 6 & 2 \\
\hline Some. Disagree & 3 & $19 \%$ & $16 \%$ & 2 & 1 & 2 & 1 & 1 & 2 \\
\hline Strong Disagree & 4 & $25 \%$ & $25 \%$ & 4 & & 4 & & 1 & 3 \\
\hline
\end{tabular}

$\mathrm{Q}$ : The ridings of Ministers get better services and more funding from government than the ridings of Regular Members.

Despite every Minister disagreeing, only one Regular Member was of like mind. There appears to be a substantial difference of opinion between the two sides, which has remained consistent through the years. 
The transparency allowed by consensus government to enable the Regular Members greater access to information and government decision making is essential for the smooth operation of responsible government in the Northwest Territories. This is evident by the majority who agree that they have influence on government policy, both on the riding and territorial level, and the feeling that they are listened to seriously by the Executive. However, there are also a substantial number who feel that the government pays more heed to the bureaucracy than to the Regular Members, that the constituencies of Ministers receive better services and that too many of the important decisions are made outside of the public eye. 


\section{$\underline{\text { Responsiveness }}$}

The ability of elected representatives to respond to the needs of their constituents is vital in any democracy. In the North, with the previously noted "hypersensitivity on the part of Members to constituency concerns ${ }^{9132}$, the ability to act, and to be seen as acting effectively, is important. Unconstrained by party platforms, whips, leaders or ideology, the MLAs in consensus government are free to speak their minds upon any subject. $^{133}$ - One Member stated:

The ability of MLAs to raise issues from their constituents on a daily basis when the House is in session, that to me is the biggest strength. I can get an issue one day and raise it in the House the next day, it's that quick, if the issue is big enough, and I believe it warrants some answers in the House, you raise it on the floor of the House, that's effective government, where constituents can feel that their issues are being taken seriously and that they are going to be raised by their MLA.

Members see this ability as one of the greatest strengths of consensus government, with another Member saying "I think the greatest strength is that there's a flexibility there to really hear the people's needs, as opposed to the party system where the party's needs come first, and I find that I'm able to speak with everybody and represent them as an MLA."

These statements, echoed by their colleagues, are further supported when the Members were asked "The consensus system allows me to represent my constituents more effectively than under the party system."

\footnotetext{
${ }^{132}$ White, $b$, p. 325

${ }^{133}$ Choosing a day at random to look through Hansard reveals this tendency. On February 15,2008 , the Regular Members asked questions on the GNWT public service reductions, the condition of a community arena, the condition of an access road, reducing speed limits on a bridge, updating licence plates, money for future construction projects, and an aftercare treatment program among others. Hansard of the Northwest Territories, http://www.assembly.gov.nt.ca/ live/documents/documentManagerUpload/hn080215.pdf
} 


\begin{tabular}{|l|c|c|c|c|c|c|c|c|c|}
\hline Table 26 & Number & $\%$ & $\begin{array}{c}\text { White } \\
\%\end{array}$ & Minister & MLA & Aboriginal & $\begin{array}{c}\text { Non- } \\
\text { Aborig. }\end{array}$ & Urban & Rural \\
\hline Strong Agree & 13 & $81 \%$ & -- & 6 & 7 & 9 & 4 & 7 & 6 \\
\hline Some. Agree & 3 & $19 \%$ & -- & & 3 & 1 & 2 & 2 & 1 \\
\hline Some. Disagree & 0 & $0 \%$ & -- & & & & & & \\
\hline Strong Disagree & 0 & $0 \%$ & -- & & & & & & \\
\hline
\end{tabular}

The results were unanimous in agreement that consensus government allowed for more effective representation, with a majority in every category in strong agreement. Several Members spoke despairingly about the state of politics in Parliament, others used the Yukon or Alberta as examples to not follow. ${ }^{134}$ It is a strong possibility that Members, upon deciding that partisan minority governments are dysfunctional, prefer the consensus system with its strong focus on constituencies instead of platforms.

For the MLAs themselves, when given a choice between being involved in the decisions for funding specific projects, or deciding the principles underlying major government policies, the majority opted for the policies, although with some interesting divisions.

\begin{tabular}{|l|c|c|c|c|c|c|c|c|c|}
\hline Table 27 & Number & $\%$ & $\begin{array}{c}\text { White } \\
\%\end{array}$ & Minister & MLA & Aboriginal & $\begin{array}{c}\text { Non- } \\
\text { Aborig. }\end{array}$ & Urban & Rural \\
\hline Specific & 5 & $36 \%$ & $43 \%$ & 2 & 3 & 5 & & 1 & 4 \\
\hline Principles & 9 & $64 \%$ & $57 \%$ & 2 & 7 & 3 & 6 & 7 & 2 \\
\hline
\end{tabular}

Q: As an MLA, is it more important for you to be involved in: decisions about funding of specific projects and about levels of service in government programmes OR decisions on the principles underlying major government policies.

*It should be noted that two Ministers checked both boxes.

Among the most interesting divisions is the fact that every Non-Aboriginal, and almost every urban MLA chose the principles as being more important, whilst the majority of Aboriginal and rural Members selected funding specific projects as their priority. This result demonstrates one of the most fundamental divisions in the Legislature. Due to the population base in the larger centres, and the existence of municipal taxes, the larger

\footnotetext{
${ }^{134}$ One Member referred to Alberta as a "one-party state".
} 
communities have several recreational amenities, including multiple gymnasiums, swimming pools, and ice rinks, operated by the city or town budgets. In the smaller communities, however, it is the territory that funds the majority of these facilities through the local band or hamlet councils, in addition to other vital services, with water delivery and sewage disposal being primary. ${ }^{135}$ With limited resources, the amenities for those communities are likewise limited. Therefore, being able to influence a decision over what communities will receive new infrastructure is of vital importance.

With that in mind, it helps to explain the next result. When given three options in a scenario that pits one Member's constituency against another's for a similar project, but with only enough funding for one, the majority of Members, instead of trying to convince the Minister to fund theirs, would rather try to convince the Minister to fund both, by taking money from elsewhere in the department's budget.

\begin{tabular}{|l|c|c|c|c|c|c|c|c|c|}
\hline Table 28 & Number & $\%$ & $\begin{array}{c}\text { White } \\
\%\end{array}$ & Minister & MLA & Aboriginal & $\begin{array}{c}\text { Non- } \\
\text { Aborig. }\end{array}$ & Urban & Rural \\
\hline Yours & 4 & $29 \%$ & $25 \%$ & 1 & 3 & 2 & 2 & 4 & \\
\hline Share & 1 & $7 \%$ & $13 \%$ & 1 & & 1 & & & 1 \\
\hline Both & 9 & $64 \%$ & $63 \%$ & 3 & 6 & 6 & 3 & 4 & 5 \\
\hline
\end{tabular}

Q: If you and another MLA both wanted government funding for similar projects in your ridings, but the Minister said that there was not enough money for both projects, would you most likely: A. Try to convince the Minister that your project should be funded rather than the other Member's project. B. Agree to split the available money with the other Member's project or C. Try to convince the Minister to fund both projects by taking money from another part of the department's budget.

Government funding for a project is often of great importance, for both the social and economic well-being of a small community. This result is also indicative of the basic principles of consensus government, as one Member put it, "The elders have always said work together, resolve issues together, not this one party beating on another party where nothing is resolved. Compromise, consensus, agreement."

\footnotetext{
${ }^{135}$ Most small communities rely on a truck based delivery service for water and sewage, as underground sewage and water lines are unfeasible.
} 
With the difference between the large and small communities, it is unsurprising that a majority of Members feel that Northerners do not all face the same problems and do need different things from the government.

\begin{tabular}{|l|c|c|c|c|c|c|c|c|c|}
\hline Table 29 & Number & $\%$ & $\begin{array}{c}\text { White } \\
\%\end{array}$ & Minister & MLA & Aboriginal & $\begin{array}{c}\text { Non- } \\
\text { Aborig. }\end{array}$ & Urban & Rural \\
\hline Strong Agree & 1 & $6 \%$ & $33 \%$ & & 1 & & 1 & 1 & \\
\hline Some. Agree & 5 & $31 \%$ & $33 \%$ & 2 & 3 & 3 & 2 & 4 & 1 \\
\hline Some. Disagree & 5 & $31 \%$ & $25 \%$ & 2 & 3 & 4 & 1 & 1 & 4 \\
\hline Strong Disagree & 5 & $31 \%$ & $8 \%$ & 2 & 3 & 3 & 2 & 3 & 2 \\
\hline
\end{tabular}

Q: Although there are important social divisions in the NWT, when you get down to fundamentals, all Northerners face pretty much the same problems and need pretty much the same things from government.

It is interesting to note how much this attitude has changed in the past twenty years. The percentage shift may be explained in part by the greater number of urban MLAs in the House, as opposed to the small constituencies which were dominant prior to division. The majority of rural MLAs feel that Northerners require different things from government, whereas a slight majority of the urban Members feel otherwise. One Member explained "Right now it seems no matter where the consideration is placed, if it's small community there is an objection from the larger centers, we invest in larger centers and there are objections from the smaller communities, so it is very difficult to keep everyone happy and very difficult to try to get everyone to think globally. Two groups within one government seem to have built walls around each other."

There is a belief among some Members that government should be as close to the people as possible. Being that the majority of government spending goes towards services such as healthcare, education and infrastructure, this is not surprising in a region where medivacs are common and residential schools a living memory. Some Members expressed hope that upon settling the outstanding land claims in the territory, the services provided would be more responsive to individual community needs. "Hopefully it will 
improve service for small communities. I think given the responsibility to govern their own affairs, aboriginal governments would maybe not do a better job but would definitely be more in tune with what is happening at a community level." With the sensitivity to community needs, a small majority of Members support allowing communities to decide if a law or regulation will apply within their jurisdiction.

\begin{tabular}{|l|c|c|c|c|c|c|c|c|c|}
\hline Table 30 & Number & $\%$ & $\begin{array}{c}\text { White } \\
\%\end{array}$ & Minister & MLA & Aboriginal & $\begin{array}{c}\text { Non- } \\
\text { Aborig. }\end{array}$ & Urban & Rural \\
\hline Strong Agree & 2 & $13 \%$ & $42 \%$ & 2 & & 2 & & & 2 \\
\hline Some. Agree & 7 & $44 \%$ & $17 \%$ & 1 & 6 & 4 & 3 & 4 & 3 \\
\hline Some. Disagree & 3 & $19 \%$ & $38 \%$ & 3 & & 3 & & 1 & 2 \\
\hline Strong Disagree & 4 & $25 \%$ & $4 \%$ & & 4 & 1 & 3 & 4 & \\
\hline
\end{tabular}

Q: Whenever possible (and certainly much more often than now) local communities should be able to decide for themselves whether a law or regulation should apply to them.

The important qualifier in the question is 'whenever possible'. There is no question that the Charter of Rights and Freedoms would apply in every situation, in addition to any applicable federal statute. One precedent for the territorial regulations is the ability of communities to hold referenda on liquor access. Several communities throughout the Northwest Territories and Nunavut are 'dry', with alcohol sale and consumption prohibited within their boundaries. Considering the isolation of many of these communities, this is a substantial restriction. However, the fear that permitting this discretion on a broader level could result in a hodgepodge of law across the territory may be the reason almost half of the Members are opposed.

A further development has been the shift from group values to a more individualistic approach. When asked if the rights or needs of the group supersede the rights or needs of an individual of that group, the majority now disagree, in direct contrast to Professor White's findings. 


\begin{tabular}{|l|c|c|c|c|c|c|c|c|c|}
\hline Table 31 & Number & $\%$ & $\begin{array}{c}\text { White } \\
\%\end{array}$ & Minister & MLA & Aboriginal & $\begin{array}{c}\text { Non- } \\
\text { Aborig. }\end{array}$ & Urban & Rural \\
\hline Strong Agree & 1 & $6 \%$ & $17 \%$ & & 1 & & 1 & 1 & \\
\hline Some. Agree & 4 & $25 \%$ & $50 \%$ & 3 & 1 & 3 & 1 & 1 & 3 \\
\hline Some. Disagree & 8 & $50 \%$ & $25 \%$ & 3 & 5 & 6 & 2 & 4 & 4 \\
\hline Strong Disagree & 3 & $19 \%$ & $8 \%$ & & 3 & 1 & 2 & 3 & \\
\hline
\end{tabular}

Q: In situations where the rights or needs of an individual conflict with the rights or needs of the group to which the individual belongs, the group should almost always be favoured over the individual.

In addition to this, a majority of MLAs now disagree with the idea of cultural or ethnic approval for legislation that impacts those groups. Where twenty years ago, $63 \%$ felt that legislation that strongly affected one of the major cultural groups would require a majority of Members of that group to agree, whether or not the House voted in majority, now, $63 \%$ feel that such approval is unnecessary.

\begin{tabular}{|l|c|c|c|c|c|c|c|c|c|}
\hline Table 32 & Number & $\%$ & $\begin{array}{c}\text { White } \\
\%\end{array}$ & Minister & MLA & Aboriginal & $\begin{array}{c}\text { Non- } \\
\text { Aborig. }\end{array}$ & Urban & Rural \\
\hline Strong Agree & 0 & $0 \%$ & $42 \%$ & & & & & & \\
\hline Some. Agree & 6 & $38 \%$ & $21 \%$ & 3 & 3 & 6 & & & 6 \\
\hline Some. Disagree & 4 & $25 \%$ & $17 \%$ & 1 & 3 & 2 & 2 & 4 & \\
\hline Strong Disagree & 6 & $38 \%$ & $21 \%$ & 2 & 4 & 2 & 4 & 5 & 1 \\
\hline
\end{tabular}

Q: On major issues which strongly affect on of the NWT's principal cultural groups (Dene, Métis, Inuvialuit, nonAboriginal), a majority of the MLAs of that group should have to agree to the decision, whether or not an overall majority of the House agrees.

Of interest, every MLA from an urban riding disagrees, whereas almost every Member from a rural constituency agrees. The reversal in support for this idea is therefore attributable to the demographic shift in the House in favour of urban constituencies. This shift, which can be traced back to the Friends of Democracy verdict, leads some Members to fear for the future of the less populous ridings. One Member stated "geography is no longer an element because of the numbers game now, and for me that was probably the worst thing that we've ever done. This legislature doesn't have that northern flavor that it had in the past." However, there is an acknowledgement by Members that the consensus system mitigates some of that loss, "I really feel that if we 
didn't have consensus government, the smaller communities wouldn't be well represented."

The urban rural split may also be responsible for the Members dividing on whether one political system can truly be satisfactory for all Northerners. The difference of historical political traditions between the Aboriginals and the non-Aboriginals who have made the North their home is substantial. However, many non-Aboriginals in the North, and the Assembly, were born and raised in the territory, and others have spent the vast majority of their adult years in the North. It is impossible to say that these people are not Northerners. Therefore it is unsurprising that both Aboriginal and non-Aboriginal Members are split evenly on whether one system can be truly satisfactory to all cultural groups.

\begin{tabular}{|l|c|c|c|c|c|c|c|c|c|}
\hline Table 33 & Number & $\%$ & $\begin{array}{c}\text { White } \\
\%\end{array}$ & Minister & MLA & Aboriginal & $\begin{array}{c}\text { Non- } \\
\text { Aborig. }\end{array}$ & Urban & Rural \\
\hline Strong Agree & 2 & $13 \%$ & $33 \%$ & & 2 & 1 & 1 & 1 & 1 \\
\hline Some. Agree & 6 & $38 \%$ & $21 \%$ & 3 & 3 & 4 & 2 & 3 & 3 \\
\hline Some. Disagree & 6 & $38 \%$ & $25 \%$ & 2 & 4 & 4 & 2 & 4 & 2 \\
\hline Strong Disagree & 2 & $13 \%$ & $21 \%$ & 1 & 1 & 1 & 1 & 1 & 1 \\
\hline
\end{tabular}

Q: The different cultural groups in the NWT have such different political traditions and their political objectives are so different that any political system satisfactory to one is bound to be unsatisfactory to others. ("Political system" in this question means methods and institutions of governing.)

While the Members are split on whether one system will ever be truly satisfactory to all people, it is interesting to note that all Members expressed satisfaction with the consensus system, and the ability therein for extensive constituency consultation and input. One Member put it as "We could go on and on about consensus government but I think there's aspects of it today that work, the constituency MLA has a tremendous voice for the people if they use it, and that is not something I would like to see taken away, that's the aspect of consensus government that is by far the best." 
One area that may be a cause of dissatisfaction with the current system is the view that Members focus too strongly on their own constituencies, without considering the needs of other ridings. There is high concurrence among Members, with $75 \%$ agreeing.

\begin{tabular}{|l|c|c|c|c|c|c|c|c|c|}
\hline Table 34 & Number & $\%$ & $\begin{array}{c}\text { White } \\
\%\end{array}$ & Minister & MLA & Aboriginal & $\begin{array}{c}\text { Non- } \\
\text { Aborig. }\end{array}$ & Urban & Rural \\
\hline Strong Agree & 4 & $25 \%$ & $33 \%$ & 1 & 3 & 3 & 1 & 2 & 2 \\
\hline Some. Agree & 8 & $50 \%$ & $29 \%$ & 3 & 5 & 5 & 3 & 5 & 3 \\
\hline Some. Disagree & 4 & $25 \%$ & $25 \%$ & 2 & 2 & 2 & 2 & 2 & 2 \\
\hline Strong Disagree & 0 & $0 \%$ & $13 \%$ & & & & & & \\
\hline
\end{tabular}

Q: When it comes to government funding or services, MLAs think too much about their own ridings, and don't consider whether other Members' ridings need the services more.

This represents an increase over the past twenty years. One possible cause is the increase in regional leaderships around the territory, compelling Members to focus more of their time to satisfying demands from within their own riding. One Member explained, "in my riding, we have 5 different leaderships, Chiefs, mayors, Métis presidents, separate agencies and boards, chairpersons so you have, I counted mine, I think I have to deal with in my riding, with 17 different levels of leadership and all different cultures." Combined with the small populations of the ridings and familiarity of constituents with their MLA, Members can face heavy pressure to deliver government services to their ridings.

A strong majority of Members feel that a good balance has been struck in the Assembly in dealing with local and territorial issues. When given an option to spend more time dealing with territorial issues, localized community specific issues or to keep the present balance between the two, the predominant choice is to remain as it is now.

\begin{tabular}{|l|c|c|c|c|c|c|c|c|c|}
\hline $\begin{array}{l}\text { Table } \\
35\end{array}$ & Number & $\%$ & $\begin{array}{c}\text { White } \\
\%\end{array}$ & Minister & MLA & Aboriginal & $\begin{array}{c}\text { Non- } \\
\text { Aborig. }\end{array}$ & Urban & Rural \\
\hline Local & 1 & $6 \%$ & $4 \%$ & & 1 & 1 & & & 1 \\
\hline NWT & 4 & $25 \%$ & $46 \%$ & 2 & 2 & 2 & 2 & 4 & \\
\hline Balance & 11 & $69 \%$ & $50 \%$ & 4 & 7 & 7 & 4 & 5 & 6 \\
\hline
\end{tabular}


Q: Assuming that the House will continue to sit for about the same length of time that it now sits, should it: A. Spend more time dealing with the specific problems of individual communities, B. Spend more time dealing with basic issues that affect the entire NWT or C. Keep the present balance between local and territorial issues.

This result indicates that most Members are content with the current balance, but that there is sentiment among the urban Members that more attention should be paid to territorial issues. These Members, coming from multi-constituency communities, may feel that their local issues are adequately addressed, and that their ridings may benefit more from a greater emphasis on the territory as a whole. As the centres have the major facilities, hospitals, treatment facilities, correctional institutions and higher education, territorial issues can also be large centre specific. There have been attempts in the past few years to move some of the territorial facilities out of Yellowknife and into the smaller communities, efforts that have been resisted by Yellowknife MLAs. It is possible that some urban MLAs feel that a greater emphasis on territorial issues may result in greater support for institutions to remain in larger centres.

While critics of consensus government cite lengthy delays in the legislative process as a shortcoming of the system, several Members expressed this very feature as one of the strongest aspects of the territorial legislature. One Member said "If we do not solve an issue, we deliberate until we compromise then we go out into the communities and say okay this was an issue, this is what we've done, this is where we are going with it." Another Member explained the process as such: "Of course consensus government doesn't lend itself to quick transition, if we had party politics, the winning party would have a platform, and you would move to implement your platform immediately. Consensus government, by its very nature, requires that everybody gets together and everybody agree on the priorities and then you move forward with a course of action." The ability of leaders to bring all sides together and to reach agreement on contentious 
issues is cited by most Members as more important than a leader being able to make a decision on a difficult issue.

\begin{tabular}{|l|c|c|c|c|c|c|c|c|c|}
\hline Table 36 & Number & $\%$ & $\begin{array}{c}\text { White } \\
\%\end{array}$ & Minister & MLA & Aboriginal & $\begin{array}{c}\text { Non- } \\
\text { Aborig. }\end{array}$ & Urban & Rural \\
\hline Make decisions & 4 & $25 \%$ & $45 \%$ & 1 & 3 & 3 & 1 & 3 & 1 \\
\hline Build consensus & 12 & $75 \%$ & $55 \%$ & 5 & 7 & 7 & 5 & 6 & 6 \\
\hline
\end{tabular}

Q: What's more important in a leader? The willingness to make a decision on a controversial issue if he or she believes it is the right thing to do OR the ability to draw people together and reach agreement on contentious issues.

Support for a consensus builder has increased significantly over the past twenty years. Furthermore, a majority in every demographic was in favour of a consensus builder. This indicates that Members favour the current method of selecting the Premier and Executive Council over the decisiveness and swifter action offered by parties. The high percentage of non-Aboriginal Members who support a compromising leader shows a strong willingness to work within the system, rather than impose a partisan style government of the South.

The ability of Members to quickly respond to their constituents, and be effective representatives for their ridings is cited by many Members as the greatest strength of consensus government. Despite divisions over whether all Northerners require the same things from government, if one form of government can meet all Northerners' needs and giving communities power over which laws to enforce, the MLAs responses indicate a high level of satisfaction with the current system, in a large part due to their ability to help their constituents. One Member said "I think running as independents, basically that's what consensus government is, represents a people as a whole, and that's always been my platform, the people have a voice." The ability of Members from both sides of the House to influence government priorities and spending for the ridings was another point often mentioned. One Member addressed this specifically: 
the ability to respond [under consensus government] to issues that come up from time to time, like we just got 230 million dollars, in most cases, the government would take that money and put it towards their priorities and their coffers and spend it anyway they want. As consensus government, we do have a say in how we spend 235 million [sic] and will those dollars be allocated by certain priorities and we may see as crucial, road to gravel pits, chip-seal the highway system, give money to communities that they can implement their own infrastructure.

Members feel free to act as they see fit, in the best interests of their riding. Free of party constraints, Members often walk down the hall from their offices into those of the Executive Council to speak with Ministers personally trying to resolve certain issues. For one Member, this was viewed as a more efficient system, "without party politics, we can get more done with consensus government; it's just easier to work with because you can go down to the Minister and it is done. I'm not crossing party lines, the way we're doing things now, it gets things done quicker."

While this can result in a riding-centric focus for Members, to the detriment of territorial issues, Members seem content with the current balance of issues that come before the House, and feel strongly that having a leadership that can bring everyone together is by far more important than having an agenda imposed upon the House. It is through compromise that Members feel they can best serve their constituents. 


\section{$\underline{\text { Adaptability }}$}

Using consensus government, the Legislative Assembly of the Northwest Territories has revealed an astonishing ability to adapt to changing circumstances. No other jurisdiction in Canada has ever had to deal with the loss of over two thirds of its territory, one third of its population and $40 \%$ of its elected representatives. While it operates under Westminster principles, it has adapted to meet unique Northern needs and understandings of governance. Despite the alterations to the system that makes consensus unique, it remains, as Professor White argued, a Westminster style government. The basic tenets of a parliamentary system are "ministerial responsibility, cabinet solidarity, the confidence convention, exclusive cabinet prerogative to bring forward taxation and spending measures and the like"136, which he notes predate the rise of political parties.

While the Assembly was not always viewed as a legitimate government by Aboriginal people in the early years of responsible government, the use of the consensus system has mitigated that initial distrust to a large degree. One Member explained:

[i]t's a unique system that incorporates the Aboriginal view of life and how they work with consensus and it's taking account of the Aboriginal culture and trying to understand it. Sometimes is just as easy to not do that because it's very complex to make sense of sometimes. But our parliamentary system, the Westminster system, doesn't make sense to the Aboriginal communities! We've got rules and structures that don't make sense [to the Aboriginal communities], so I think that's what makes us strong, makes us be patient and understand each other and the system that we have developed and use in the North..

Furthermore, with the consensus model approaching thirty years of stable governance, it is increasingly held by its practitioners that it is compatible with the Westminster model.

${ }^{136}$ White, a, p.503 


\begin{tabular}{|l|c|c|c|c|c|c|c|c|c|}
\hline Table 37 & Number & $\%$ & $\begin{array}{c}\text { White } \\
\%\end{array}$ & Minister & MLA & Aboriginal & $\begin{array}{c}\text { Non- } \\
\text { Aborig. }\end{array}$ & Urban & Rural \\
\hline Strong Agree & 0 & $0 \%$ & $13 \%$ & & & & & & \\
\hline Some. Agree & 2 & $13 \%$ & $46 \%$ & 1 & 1 & 2 & & & 2 \\
\hline Some. Disagree & 11 & $69 \%$ & $17 \%$ & 5 & 6 & 8 & 3 & 6 & 5 \\
\hline Strong Disagree & 3 & $19 \%$ & $25 \%$ & & 3 & & 3 & 3 & \\
\hline
\end{tabular}

Q: Our system of consensus government and the British parliamentary system are fundamentally incompatible.

The substantial increase of perceived compatibility over the past twenty years can most likely be attributed to the maturation of the system, greater exposure of the Members to other legislatures and participation in parliamentary associations. The Executive Committee employs Cabinet solidarity when voting in the House on most matters, ${ }^{137}$ votes against or abstains from motions that purport to give direction to the government and generally operates in the House as many governments do in other parliamentary minority legislatures. The use of parliamentary reference books such as Beauchesnes's Parliamentary Rules and Forms and Marleau \& Montpetit's House of Commons Procedures and Practices further ensconce the idea that the Assembly operates under parliamentary aegis.

Cabinet solidarity is not liked by all Members, with one Member stating: "The only thing that even reeks, and I use that word loosely, of party systems is the fact that Cabinet solidarity exists," however, the Member continued by saying "but I know that it needs to, that there needs to be some agreement on that level that their message is a common one." The majority of the MLAs do support the idea of a Minister not being able to publicly disagree with the government.

\begin{tabular}{|l|c|c|c|c|c|c|c|c|c|}
\hline $\begin{array}{l}\text { Table } \\
38\end{array}$ & Number & $\%$ & $\begin{array}{c}\text { White } \\
\%\end{array}$ & Minister & MLA & Aboriginal & $\begin{array}{c}\text { Non- } \\
\text { Aborig. }\end{array}$ & Urban & Rural \\
\hline Yes & 4 & $25 \%$ & $33 \%$ & & 4 & 2 & 2 & 2 & 2 \\
\hline No & 12 & $75 \%$ & $66 \%$ & 6 & 6 & 8 & 4 & 7 & 5 \\
\hline
\end{tabular}

${ }^{137}$ Cabinet solidarity has been waived during votes on motions to revoke appointments to the Executive Council. 
Q: Do you think that a Minister should be able to publicly disagree with the government and remain a Minister?

Support for Cabinet solidarity is unanimous among Ministers, indicating that they accept the fundamental reasons behind solidarity. The majority of Members likewise agree with the policy, with strong support in each category. Support may be strong due to the ability of Members to speak against initiatives during the in camera meetings of Caucus, with Ministers having a further opportunity at Cabinet meetings.

While some of the adaptations made are of an institutional nature, such as the selection of the Executive Council, other deviations from parliamentary standards are of a more personal nature. The civility of debate and orderly conduct during Question Period are often noted by outside observers. Several MLAs expressed disgust at the conduct of their counterparts in the House of Commons, and a strong desire to remain respectful of their colleagues in the House. Over $80 \%$ of the Members agreed when asked "During Question Period in legislatures in Southern Canada, Members often try to embarrass Ministers or to make them look bad, but our Legislature should not operate this way."

\begin{tabular}{|l|c|c|c|c|c|c|c|c|c|}
\hline Table 39 & Number & $\%$ & $\begin{array}{c}\text { White } \\
\%\end{array}$ & Minister & MLA & Aboriginal & $\begin{array}{c}\text { Non- } \\
\text { Aborig. }\end{array}$ & :Urban & Rural \\
\hline Strong Agree & 9 & $56 \%$ & $42 \%$ & 5 & 4 & 6 & 3 & 4 & 5 \\
\hline Some. Agree & 4 & $25 \%$ & $38 \%$ & 1 & 3 & 2 & 2 & 3 & 1 \\
\hline Some. Dis. & 2 & $13 \%$ & $17 \%$ & & 2 & 2 & & 1 & 1 \\
\hline Strong Dis. & 1 & $6 \%$ & $4 \%$ & & 1 & & 1 & 1 & \\
\hline
\end{tabular}

When compared with Professor White's findings, the results indicate that respect for their colleagues on the Executive Council is important to Members, and has remained constant throughout the years. While this is probably due to the individual-centred nature of consensus government, with no Member wishing to appear to have a personal vendetta 
against Ministers, the strong Aboriginal presence and culture of listening respectfully has also played a significant role.

Aside from the institutional adaptations the NWT legislature made to the Westminster system, the method of Executive selection, the Caucus and the expanded role of committees and the Members therein, Member seem hesitant to embark on large scale reforms. They are divided as to whether the people should be more directly consulted through referenda and plebiscites, with support for this idea declining marginally since the $1980 \mathrm{~s}$.

\begin{tabular}{|l|c|c|c|c|c|c|c|c|c|}
\hline Table 40 & Number & $\%$ & $\begin{array}{c}\text { White } \\
\%\end{array}$ & Minister & MLA & Aboriginal & $\begin{array}{c}\text { Non- } \\
\text { Aborig. }\end{array}$ & Urban & Rural \\
\hline Strong Agree & 2 & $13 \%$ & $29 \%$ & 2 & & 2 & & & 2 \\
\hline Some. Agree & 6 & $38 \%$ & $25 \%$ & & 6 & 3 & 3 & 4 & 2 \\
\hline Some. Dis. & 5 & $31 \%$ & $25 \%$ & 2 & 3 & 3 & 2 & 3 & 2 \\
\hline Strong Dis. & 3 & $19 \%$ & $21 \%$ & 2 & 1 & 2 & 1 & 2 & 1 \\
\hline
\end{tabular}

Q: The people should be directly consulted by referendums and plebiscites much more often than they are now.

Although Northerners tend to be politically engaged, especially in the smaller communities, ${ }^{138}$ there are a couple possible reasons behind the split on the part of the MLAs for this idea. Those in favour are probably those who feel the people are best served when the government is as local as possible. By having the people decide important issues, they are able to express the majority's wishes clearly. This has the added advantage of removing potentially divisive topics out of the Assembly, which, shown in an earlier table (pg. 39), is reluctant to tackle divisive issues.

Those against this idea may fear domination by the larger centres, which could impose their will through the high population concentration in Yellowknife, Hay River, Inuvik and Fort Smith. Asking the people to directly decide on issues could have the

\footnotetext{
${ }^{138}$ In the 2007 General Election, voter turnout overall was $67 \%$. Outside of Yellowknife, the average turnout was $74 \%$. Official Results of the 2007 Election, Elections NWT.
} 
effect of marginalizing the smaller communities. Others may oppose plebiscites for financial reasons. Plebiscites are expensive, in the only example in the territory's history, the 1992 plebiscite on the boundary for division cost over $\$ 851,800$. While this included what are now Nunavut ridings, the total for the Western ridings was over $\$ 315,000$, with another $\$ 235,350$ for the Plebiscite Office. With five new ridings since created, it is logical to assume another $\$ 100,000$ should be added to cover expenses there. ${ }^{139}$ Running even one plebiscite a year would be an inordinate expense for the Assembly, running close to, if not over, one million dollars. ${ }^{140}$

On the whole, Members are pleased with consensus government, with unanimous agreement that it will continue to meet future needs of the Assembly.

\begin{tabular}{|l|c|c|c|c|c|c|c|c|c|}
\hline Table 41 & Number & $\%$ & $\begin{array}{c}\text { White } \\
\%\end{array}$ & Minister & MLA & Aboriginal & $\begin{array}{c}\text { Non- } \\
\text { Aborig. }\end{array}$ & Urban & Rural \\
\hline Strong Agree & 9 & $56 \%$ & --- & 5 & 4 & 6 & 3 & 5 & 4 \\
\hline Some. Agree & 7 & $44 \%$ & - & 1 & 6 & 4 & 3 & 4 & 3 \\
\hline Some. Dis. & 0 & $0 \%$ & -- & & & & & & \\
\hline Strong Dis. & 0 & $0 \%$ & -- & & & & & & \\
\hline
\end{tabular}

Q: The consensus system will continue to meet our needs in the future.

Such strong support indicates that Members feel the consensus system has been effective and is likely to continue being so.

When presented with alternative systems, with political parties and the direct election of the premier being the most frequently suggested, the majority of MLAs feel that changing the existing system would bring no greater benefits. It has been suggested that parties would bring greater vision to the Assembly and swifter action when a new party comes to power to implement their vision. Most Members, however, disagree.

\footnotetext{
${ }^{139}$ The average per riding was over $\$ 20,000$. Report of the Chief Plebiscite Officer, May 2, 1992 Plebiscite.

${ }^{140}$ Monetary figures are from 1992, Bank of Canada's Inflation Calculator suggests a $35 \%$ increase due to inflation. http://www.bank-banque-canada.ca/en/rates/inflation calc.html

Higher salaries and facility rentals should also be taken into account.
} 


\begin{tabular}{|l|c|c|c|c|c|c|c|c|c|}
\hline Table 42 & Number & $\%$ & $\begin{array}{c}\text { White } \\
\%\end{array}$ & Minister & MLA & Aboriginal & $\begin{array}{c}\text { Non- } \\
\text { Aborig. }\end{array}$ & Urban & Rural \\
\hline Strong Agree & 1 & $6 \%$ & --- & & 1 & & 1 & 1 & \\
\hline Some. Agree & 1 & $6 \%$ & --- & & 1 & & 1 & 1 & \\
\hline Some. Dis. & 6 & $38 \%$ & --- & 2 & 4 & 3 & 3 & 5 & 1 \\
\hline Strong Dis. & 8 & $50 \%$ & -- & 4 & 4 & 7 & 1 & 2 & 6 \\
\hline
\end{tabular}

Q: Having political parties would allow for a more long term vision for the NWT.

While the media has correctly identified the fact that most voters have little chance to judge a candidate on their vision for the territory as a whole, by electing an individual who they consider the most effective, voters do receive a representative who has significant say in the territorial vision of the new Assembly. "So I think an advantage in our system, Members are more in tune to what the plans of government are, and can affect them earlier on rather than engage in rather pointless debate in the assembly." Another Member contrasted the two systems as thusly "if the new party gets in there's a big change in direction in government. With us the changes are more subtle, more hardfought, more hard-won, and slower as well. That can be good as well as bad."

When asked outright if they would prefer operating under a party system, a strong majority of MLAs said no. Several Members addressed parties during the interviews, with many viewing parties as a good reason to stay with consensus. As one Member stated, "Talking here amongst the other MLAs, I get a sense that a majority of us support the concept of a consensus government given the realities of the NWT." The strength of the individual MLA and the independence the system grants are among the main reasons. "I really like the independence, if they had parties, I'm not sure what party I would belong to, probably a NWT party, but I really like the independence of consensus government and the right to vote anyway you see fit, not vote this way because the whole party is voting this way, that's something I could never agree with." Another Member 
said "If I was in a party politics system and I believed in something passionately, and they say well you can't say that because this is the party line, I'd leave the party, I just couldn't do it."

Support for political parties has declined among Members in the past twenty years. A partisan legislature is summarily rejected by every Aboriginal Member.

\begin{tabular}{|l|c|c|c|c|c|c|c|c|c|}
\hline Table 43 & Number & $\%$ & $\begin{array}{c}\text { White } \\
\%\end{array}$ & Minister & MLA & Aboriginal & $\begin{array}{c}\text { Non- } \\
\text { Aborig. }\end{array}$ & Urban & Rural \\
\hline Yes & 2 & $13 \%$ & $21 \%$ & & 2 & & 2 & 2 & \\
\hline No & 13 & $87 \%$ & $79 \%$ & 5 & 8 & 9 & 4 & 6 & 7 \\
\hline
\end{tabular}

Q: Do you want to have political parties in territorial politics?

The decline in support may be due to a couple factors. In the early Assemblies, consensus government was seen by some Members as a stop-gap measure, that a partisan legislature was inevitable and desirable, as an indication of a mature political system. Several Non-Aboriginal Members advocated for parties, with some even running for reelection under a party banner. Others tried to organize Members within the Assembly. The Yukon, which up until the 1970s had followed much the same evolutionary course as the Northwest Territories, had political parties run in territorial elections from 1970 onwards, and by 1978, "it was realized that the only system which would work in the legislature was the traditional party system to guarantee the government enough voting strength for the passage of new policies and programs."141 It is clear, however, that Members now believe consensus to be a valid, and mature, form of government. Several past Members, who upon initially being elected wanted to have parties, expressed mea culpa at the very thought after spending time in the existing system. Former Member Brendan Bell stated in 2003 "Four years ago when I was elected to this institution, I

${ }^{141}$ Chris Pearson, “Yukon's Responsible Government”, in Canadian Parliamentary Review, vol. 3, no. 1, 1980. 
believed that somehow there was a need for us to throw off the shackles of consensus government and move to what I perceived at that point as a more mature style of government. I'm happy to say that I was absolutely wrong at that time."142 Former Dean of the House Charles Dent, in an interview given shortly before his retirement in 2007, listed consensus as the government accomplishment of which he is most proud. ${ }^{143}$

The proposal to elect the Premier at large represents a significant departure from the Westminster model. While the argument is made that with the absence of parties, this would allow for more direct accountability of the Premier to the public, it throws into question one of the basic tenets of parliamentary governance, the confidence convention. This convention has been modified in the territorial legislature to include the consent of the House to be led by an individual. If the Premier was elected at large, the House would have no say over the chair of the Executive Council, thus would be unable to express its consent. The question remains unanswered as to whom the directly elected Premier would be accountable, to the people at large, once every four years, or to the House, as is currently the case? When the Members were asked if they were in support of having the Premier elected at large, the majority said no.

\begin{tabular}{|l|c|c|c|c|c|c|c|c|c|}
\hline $\begin{array}{l}\text { Table } \\
44\end{array}$ & Number & $\%$ & $\begin{array}{c}\text { White } \\
\%\end{array}$ & Minister & MLA & Aboriginal & $\begin{array}{c}\text { Non- } \\
\text { Aborig. }\end{array}$ & Urban & Rural \\
\hline Yes & 4 & $25 \%$ & -- & & 4 & 1 & 3 & 3 & 1 \\
\hline No & 12 & $75 \%$ & -- & 6 & 6 & 9 & 3 & 6 & 6 \\
\hline
\end{tabular}

Q: Do you think that the Premier should be directly elected by the people in a general election?

However, those who were in support identified backroom politics as a motivating factor. One Member said "I don't believe the Premier should be elected from amongst the 19, because it gets back to a popularity contest from amongst the 19, it gets into a lot of back

\footnotetext{
${ }^{142}$ Territorial Leadership Committee Hansard, December 10, 2003. .

143 "Looking back, looking forward: Charles Dent is interviewed by Pearl Benyk", May 2007, posted on Dent's website at http:/www.charlesdent.com/news_letter/2007/june2007.pdf
} 
room manoeuvring, promises, friendships, family, you name it. I think having the Premier elected at large by the people would be a tremendous step for the territory." The perception of backroom collusion in the selection for the most politically powerful office in the territory is disturbing, and a valid point of concern. However, equal care must be taken to ensure the solution does not cause even greater problems. As another Member said,

Premiers have been brought down right in the house and premiers are very well aware of the fact that they're there at the will of the House and so they tend to operate knowing that and within the parameters. If the premier was elected at large, I've never been able to get a good grasp on exactly how you would hold him accountable and how he would operate in that situation; I guess it would depend on how he wants to cooperate with the Members. As far as an accountability issue, I don't see it working well in our style of government.

While the consensus model has been able to adapt to changing circumstances, having a directly elected Premier would challenge all the preexisting notions of accountability of the Executive to the House. Having a popularly elected Executive sitting within the legislative body is unprecedented in parliamentary practice. ${ }^{144}$

Although consensus government operates without parties, contrary to Disraeli's belief "without Party, Parliamentary government is impossible"145, one must bear in mind that parties evolved after the evolution of the parliamentary tradition. Some parallels may be drawn between the monarch asking a British parliamentarian to form a government in the $18^{\text {th }}$ century, and the Commissioner inviting the elected members of the Executive Committee to choose a Government Leader in 1979. Issues once formed

\footnotetext{
${ }^{144}$ In the Nunatsiavut Assembly for the Inuit of Labrador, the popularly elected President presides over the Assembly as Speaker, and acts as Chair of Executive Council meetings. Nunatsiavut Constitution, s.3.2.12 http://www.nunatsiavut.com/pdfs/Constitution.pdf As this Assembly is still under development, it may not be able to be classified as a Westminster parliamentary government. In addition to elected Members, the Assembly is also comprised of Chairs of Community Corporations. The elections for President take place in October, 2008. Eligibility for the Assembly and Presidency is restricted to Labrador Inuit.

${ }^{145}$ Quoted in White, $a$, p.503
} 
the blocs, instead of ideology, and it has been this principle by which many votes have been decided in the Legislative Assembly. Consensus government has adapted parliamentary procedures to meet specific needs inherent to Northern society. Fundamentally, it remains true to Westminster principles. 


\section{Future Challenges}

The political landscape of the Northwest Territories has been subject to constant changes since the introduction of responsible government, and this trend will continue into the future. With the Aboriginal land claims and self government agreements beginning to be settled, a new level of government has started to come into being. Ongoing discussions with Ottawa over the further devolution of power to the territory, especially over resources, may result in substantial changes to the territorial budget and fiscal operations. Burgeoning development has finalised the transition to a wage-based economy in many of the small communities, with concomitant consequences. Faced with these challenges, the role of the Legislative Assembly is far from certain.

Members are well aware of the challenges they and their colleagues face. When asked to look ahead to predict what may come in the future, Members spoke of selfgovernments cooperating or competing with the territorial government,' continued disputes over new and existing ridings, and further evolution of the Legislative Assembly itself, with some Members predicting a second chamber.

\section{Ridings - The fight continues}

A perennial challenge for the Assembly has been dividing Members since the earliest Assemblies. The ridings are determined by geography, culture, and population. With the vast expanse and sparsely populated land, it is only natural that there are unavoidable variances in the ridings, in terms of population, number of communities and the physical size. The debates over altering the number of ridings and the boundaries of ridings, however, are among the most contentious and divisive debates in the House. 
Members have been reluctant to further expand the House from the current nineteen. The NWT Act allows for a maximum of 25 Members, and the most recent boundaries commission, which filed its report in 2006 , recommended the addition of two new seats. The recommendations, however, were voted down in the House. As one Member said, "you can pick holes in everything, you can find ways that don't work but when you get right down to it, for the people, for the territory we represent, the number of people we represent, the size of the geographical area that we represent, and the number of members that we have, I think it's pretty hard to beat the representation we get across the territory right now." This is true, as the average population of ridings is 2253 , although deviations from this mean range from $-59 \%$ (or 935 ) to $+38 \%(3126){ }^{146}$ However, most of the underrepresented ridings are in urban centres, and are geographically compact with only two of those ridings having more than one community. As one Member pointed out, "here in Yellowknife, we've got seven MLAs and there are eight city councillors. We're almost to the level of eight city councillors; it just gets a little bit ridiculous after a while."

One issue that is central to this debate is population. After the Friends of Democracy ruling, any jurisdiction that is underrepresented by more than $25 \%$ has a reasonable chance of receiving a favourable verdict from the courts to increase their representation. Currently, there are four ridings at or beyond that threshold, three of which are in Yellowknife. While there is no indication that Yellowknife is seeking more representation, future population growth will reveal a weakness in the consensus system.

The Assembly, by federal law, can only accommodate six new ridings. The 2006 Boundaries Commission recommendations rectified the most glaring iniquities, yet still

${ }^{146}$ Electoral Boundaries Commission Report 2006, p.13 
left four ridings $25 \%$ over the mean, albeit by only a couple points. It is evident that the Assembly will be forced to request the federal government to amend the NWT Act if the current population ratios are to be maintained. By scanning through the numbers on the electors list from the past three elections, four of the ridings with low populations saw an increase in total voters by 81 . The four largest ridings by population saw an increase of $950 .{ }^{147}$ It is clear that the larger ridings are growing exponentially faster than the small ridings. This creates a dilemma that must be addressed. If the current population ratio is to be maintained, the Assembly will be forced to create new seats, predominantly in Yellowknife. This would have the effect of altering the balance that many Members feel is essential for consensus government. The current system is designed to ensure no one region can dominate the Assembly or the Executive Council. By continually adding new seats, it is inevitable that one region, namely Yellowknife, would gain a majority in the House. One Member explained, "[a]gain it is a matter of one center being very large and having a large population which really threatens some of our smaller jurisdictions and smaller ridings and some of the ridings may have to combine to keep enough of the voting population to justify its existence, so population has an impact." Another Member, expressing a way in which this situation would be somewhat alleviated, said "no offence to my colleague who represents Tu Nedhe, Tu Nedhe represents two small communities, two small constituencies that makes up a population of 670 people. And if they were part of say North Slave [Weledeh] or the Fort Smith [Thebacha] riding we wouldn't have this problem today."

\footnotetext{
${ }^{147}$ Ridings used are Tu Nedhe, Inuvik Twin Lakes, Nunakput and Mackenzie Delta. Due to acclamations, Inuvik Boot Lake and Deh Cho were omitted from the small riding count. The four largest ridings by population are Monfwi, Nahendeh, Frame Lake and Yellowknife Centre. To determine population, 2007 voters lists were utilized. It should be noted that the population of a riding may differ significantly from the numbers presented on voters lists.
} 
Members face a difficult decision. Either they can maintain the current number of seats, and risk a court challenge in the future, or they can make alterations to the ridings, either by adding new seats or redistributing the existing ones. One Member spoke about the difficulties faced not only due to population but geography,

It is really difficult to justify how will the ridings are created because right now population is the only factor that is being considered but there is always the argument that the size and numbers of communities should also be factored in. We have, I think, eight members who represent roughly 28 communities and the rest [eleven] represent the five or six that are remaining, so there is really an imbalance, we have ridings where one member could have one constituency meeting and he has covered his community, some of us, to ensure that everyone has access to our meetings, it will take us a week.

One of the problems is that many of the ridings that are spread over a large area with several communities are also among the smallest in population, which may exacerbate the discrepancies from the mean.

A final situation the Assembly will need to consider stems from the selfgovernment agreements. Rights-holders to the land claims are not required to live within the boundaries of the claim in order to take part in the leadership votes and electoral process of that government. However, by adding a new layer of government, it is easy to confuse the roles and responsibilities of the self-government with the territorial government, and the roles played by the respective representatives. Furthermore, as ridings are for the most part congruent with the land claims, rights-holders who are resident in another riding, most often in Yellowknife or the other centres, may wish to speak with the MLA from the self-government region, and not the MLA who represents their current household. This is understandable given the relative small numbers in land claims, many rights-holders have an established relationship with the MLA from that 
region, and they may not wish to approach a stranger with a problem. As one Member explained,

For a case argument, there are right holders of the Tli Cho government and they want to be represented by a Tli Cho person. So the 500 people would have to sign off paper and say we want a Tli Cho member representing us, but not Great Slave or Range Lake, but we are the people of the Tli Cho government, so that may become an issue because whenever we do here we must respect the agreements we have in place and they are under the Tli Cho government but at the same time live [in] the jurisdiction of [another MLA].

Traditional parliamentary procedure does not allow for constituents of one riding choosing a Member from another to represent them except under extraordinary, and temporary, circumstances. ${ }^{148}$ As more self-governments come into place, this situation may become more common, and will need to be addressed.

\section{Land Claims and Self Government - What does this mean?}

In 2003 , the first comprehensive land claim and self government agreement in the Northwest Territories was signed between the Government of Canada and the Tli'cho.

One Member described its effect on the future of the territory as such:

That is another government that is put in place in the Northwest Territories now through self-government agreements, constitutionally protected, once they draw down their authorities, they will take over the delivery of some of the programs that we now deliver, and as they draw this [power] down, they will have the lawmaking authority to make some of the changes. And as that is the base now for every other group in the territory, that will have a significant impact [on how] we operate as the government of the Northwest Territories.

There are currently several other land claim and self government negotiations ongoing, and most, if not all, will be settled within the next decade. However, the relationship between the self-governments and the territorial government is as of yet undetermined.

${ }^{148}$ The death or prolonged absence of their representative, for example. 
Some Members expressed "there's going to be a time when the GNWT is a second tier government and our aboriginal governments will be the first tier, but that will take a long, long time to develop." Others argued "If you listen to a lot of the Aboriginal governments, they say once the land claims are settled there's no need for government, period. There's no need for the GNWT. I obviously disagree because how do we deal with Yellowknife?" Others expressed concern with the division of services between the levels of government, with one Member stating "first and foremost is the capacity issue, whether the services being delivered by the GNWT are being duplicated by the regional governments, the overlap, the waste, I think there needs to be coordination on both parts so that we're not stepping on each others toes and that the resources that we do have can be used effectively to look after the people we both represent." One possible solution was suggested:

With devolution and the completion of the Aboriginal governance agreements, responsibilities will devolve, certain responsibilities should absolutely devolve to the aboriginal governments, and they should be responsible for those. Like the feds do now, they set parameters and we do our job within parameters, the same will probably be true, the federal government or the territorial government will set parameters and the Aboriginal governments will live within those parameters.

One Member saw no difficulty in the devolution, as the territory has already developed a regional manner to deliver services:

You look at the way the government set up right now, basically it's all these regional programming distribution, you have the Hay River region, the South Slave region, the Nahanni region. So we already have a geographical distribution of program responsibilities, to healthcare, social services and municipal authorities, so I think the government is structured that way already. So it's just a matter of how you allow those programs and responsibilities to be taken over by a self-governing authority. 
As further self government agreements are signed, the Assembly will be forced to consider its role in the future. It is likely that the existing structure of regional authorities for education, health and social services will be beneficial in devolving control to self governments.

One of the greatest challenges will be for the Assembly to determine what role it will play when the delivery of most services is handled by the self-governments. As one Member stated, "there will always be a need for a public government because not everybody falls under each particular land claim." With half the population of the territory not considered land claims beneficiaries, it is essential that the public government remain a relevant and strong component of responsible government in the Northwest Territories. One Member viewed this as "probably the most unique challenge we'll have to develop or work on between now and going forward by way of how the self-government agreements being settled will fit into a public government system, and aboriginal government system." One of the greatest strengths the Assembly has currently is that it can act as the forum for all regions, and all people, of the territory. If the Assembly can continue to bring unity to diversity through compromise, it will perform a unique and essential role that the individual self-governments, chartered communities, towns and city are unable to fulfill.

Accommodation - A Northern Senate?

During the course of the interviews, one suggestion was raised by several Members to deal with the challenges above. A second body or chamber is certainly not unknown to provincial legislatures, although they have all since been abolished. One 
Member viewed a second chamber as a way to incorporate the wisdom of elders into the legislative process, "their role would be more of advising the leadership and the people, advising the leader, it would incorporate some of the strong cultural advice, advice from the senior people of all nationalities to advise us as to what we should be looking at and develop a strong seniors/elders advisory committee into our style of government and have them play a more prominent role in consensus government." Others thought it the best way to incorporate the self-governments into the public government:

Is there eventually going to be a need for some sort of upper house or second house by way of, not called a Senate, but a similar arrangement for people who represent the regional government by way of self governing agreement also have an opportunity for the Aboriginal government which would be established through these self government agreements to have a role in how the government functions also hope they tie it at some point it and we have to look at that because there is implications to the implementation of those agreements.

Bringing together the self-governments and the territorial government will be important for the smooth operation of public government in the Northwest Territories. A second chamber is one way in which this could be achieved, and is worth consideration by the Assembly. Members will have to decide if it is worth the extra cost, and potentially slower legislative process. 


\section{Plus ca change...}

One major change since White's original survey is the role of the Regular Members. As the numbers in tables 12 and 13 show, an overwhelming majority think the Regular Members should stick together to put more pressure on the government, while a smaller majority think that the Regular Members are too divided or disorganized to bring down the government. The Standing Committee on Priorities and Planning is now viewed as fulfilling much the same role as the opposition parties in other Canadian legislatures, a significant departure from White's finding. (Table 14). Although the satisfaction of the Regular Members to influence government policy affecting their ridings and the territory is high (table 16), more MLAs now feel that granting the Regular Members more influence on running the government would be detrimental than before. This reveals perhaps the greatest change since White's original survey, an entrenchment of roles between the government and the Regular Members. Whether this is an evolution of consensus government, an indication of greater influence of Southern partisanship infiltrating Northern political society, or a result of natural tensions in political institutions remains to be seen.

In what is one of the most important findings of this study, every Member feels that consensus enables them to represent their constituents more effectively than under the party system. Furthermore, table 36 shows three quarters of all respondents felt that the ability to build consensus was more important in a leader than being able to make a decision on a controversial topic. This represents a $20 \%$ increase since White's survey, and may be due to the increasing acceptance of non-Aboriginal Northerners to the consensus system. Combined with the high majority who now feel that consensus is 
compatible with the Westminster system indicate that Members now view consensus as a legitimate form of governance, and not as a temporary stop-gap between direct rule of the Commissioner and partisan politics. The fact that parties are soundly rejected by Northern MLAs suggests a healthy future for consensus government.

In the years that elapsed between White's study and this one, the Northwest Territories have undergone dramatic political, economic and demographic change. Nevertheless, the consensus system has met all the challenges these changes have wrought. It is interesting to note that in many tables, where White noted a high percentage of strong agreement or disagreement, the highest percentage is now in somewhat categories. Whether this represents a growing acceptance of the status quo, a reluctance to challenge the system or a muting of strong feelings toward the system, whether supportive or critical remains to be seen.

The questions remains, "what's changed?" White concluded his survey by stating:

an effective government is more likely to be a legitimate government, and government effectiveness is very much a function of the form of government, as well as the responsiveness of the principal representative institution and the processes by which governmental decisions are made. To the extent that the Legislative Assembly of the Northwest Territories contributes to effective government by adapting the procedures and operations of the Westminster model to Northern political styles and Northern political needs, the Assembly will promote the overall legitimacy of the existing political system. ${ }^{149}$

In the years since, the Legislative Assembly has been successful in becoming regarded as the legitimate government of the Northwest Territories. While there are new governments being developed, few would argue that they will replace the Assembly outright as the body politic for the territory. This is a testament to the strengths of the

${ }^{149}$ White, $a$, pp. $522-523$ 
consensus system. Instead of grafting an alien system upon the Aboriginal people of the North, compromises were created that developed a unique merging of Aboriginal decision making with Westminster style governance.

There is far greater acceptance of the consensus system now, at least among the MLAs. There has been a solidifying of roles, although the scope of the roles remains debatable. As table 8 shows, the majority still agree that leadership on difficult issues proves elusive, but no respondent-now feels strongly in agreement. Past events may have proven that leadership is possible, and even desirable in such situations. Table 12, while still registering strong support for the Regular Members to act in concert more often, also shows a $21 \%$ drop in strong agreement, all to the somewhat agree category. The rise in power of the committees and the influence the Regular Members wield therein may be a contributing factor here. Interestingly, table 13 marks a large shift towards the somewhat agree option when Members think about whether or not the Regular Members are too divided to be able to force Cabinet to change course on policy. One of the most telling results is in table 14 , where there has been a huge shift in the perception of what the Standing Committee on Priorities and Planning does. Most now somewhat agree that it fulfills much the same function as an opposition party in Southern legislatures. In table 17, MLAs somewhat agree or disagree on whether it would be practical for Regular Members to have more influence, in contrast to the strong feelings expressed twenty years ago. This may be due to the MLAs becoming accustomed to the respective roles, and more or less content with their ability to work within the system.

Table 18 has one of the greatest shifts of support, with a large majority stating that power between the Regular Members and Cabinet has remained balanced in the past few 
years. It is also good to see that the majority now state that support for government initiatives does not hinge upon the Member's riding receiving extra government services or funding, as shown in table 20. However, support for another Member's motion or proposal does appear to be based upon gaining support for one's own initiatives. Table 21 shows a worrying increase in the 'fairly often' category.

Tables 22 and 23 show an interesting contradiction. While the majority now disagree that raising an issue publicly-in the House is the most effective way of getting it resolved, a similar majority also feel that too many issues are resolved in private. Both tables show a tendency towards the somewhat agree or disagree option, a trend which is evident in many other tables. While acceptance of the consensus system has increased, the tendency of the MLAs to respond in the somewhat agree or disagree categories indicates a lack of strong feelings either in favour or against the status quo.

Table 32 highlights one of the biggest changes since White's study. With the division of the territory, there is no longer a substantial Inuit presence in the Legislative Assembly. While this does not mean the territory is now homogenous, it is less heterogeneous, and the Dene form a clear majority. As such, it is perhaps felt that approving an act that affects one cultural group more than the others no longer requires a majority of MLAs from that group to agree. This could also be due to the rising prominence of the regional governments, which are more culturally based. A further point of interest is the drop of support among Members to discuss more territorial issues. Most feel that the present balance between local and territorial issues should be maintained, indicating that the system has achieved a suitable mechanism for dealing with local and territorial issues equitably. 
In terms of leadership, more Members express support for a leader who is capable of building consensus, rather than one who can make difficult decisions. Table 36 reveals increasing support for the consensus model. When combined with table 37 and a dramatic shift towards recognizing compatibility between Westminster and consensus, more Members seem inclined to believe that the consensus model is sustainable and effective than before. 


\section{Conclusion}

Many similarities exist between the responses given to White and to this study. The evidence points towards greater acceptance of the consensus system, but with both criticism and enthusiasm muted. Support for the consensus model among non-Aboriginal Members has increased, as has opposition to introducing political parties. While support for consensus among Aboriginal Members remains high, there is growing anticipation of what self government agreements will bring to both their people and their future. Once all the agreements are concluded, many are unsure of where that will leave the Legislative Assembly, and its practice of consensus government. The concept of the future is in all likelihood the greatest change since White's study. Where he found many non-Aboriginal Members looking towards a partisan future, now many Aboriginal Members are looking towards a future in which the Legislative Assembly may play a marginal role. The greatest challenges for consensus government are yet to be faced.

Over the past thirty years, consensus government has provided an effective and accountable form of governance to the people of the Northwest Territories. This is evidenced in the due diligence of the legislative process, a perpetual minority government that is open to compromise, an open method of selecting the Executive Council and the overwhelming belief among its practitioners that it provides the best available system for responding to the needs of their constituents. Through its unique adaptations, the Legislative Assembly of the Northwest Territories combines almost one thousand years of parliamentary practice and traditions with the even longer practice of consensus among the Aboriginal peoples. While it is by no means a perfect system, the MLAs who toil within it are to a large degree satisfied with what it enables them to do. The Regular 
Members hold the Executive to account, whether it is through exhaustive Committee review of each piece of legislation; participating in the development of a Strategic Plan for the life of the Assembly; or by outright removal of Ministers who are not performing adequately. The Regular Members are privy to an extraordinary amount of privileged information, and most are satisfied with how Cabinet responds to their queries and concerns. With the small riding size, Members are quick to respond to constituents requests, and are content with their ability to represent their riding in an accountable manner.

It is entirely possible that the consensus system will not survive. It may be undone by a large influx of people from the South who do not understand or wish to live under the system. It may be subject to segmentation, as more Aboriginal groups settle their land claims and establish self governments and view the Legislative Assembly as a secondary institution. It may succumb to internal partisanship if the territory is successful in gaining full powers from Ottawa. However, this does not deny that it has been a successful legislative forum and has been accepted as the legitimate government of the Northwest Territories by the people for whom it was designed. 


\section{Bibliography}

Susan Baldwin, "A Procedural Clerk Goes North", Canadian Parliamentary Review, Vol. 6, No. 31983

Gurston Dacks, $a$, "Consensus Government in the Northwest Territories", presented to the Annual Meeting of the Canadian Political Science Association, Montreal, May $31^{\text {st }}$, 1985

Gurston Dacks, $b$, "Consociationalism in the Northwest Territories", Canadian Journal of Political Science, Vol.19, No.2 (June 1986), pp.345-361

Mark Dickerson, Whose North?, UBC Press and the Arctic Institute of North America; Vancouver, 1992

Brian Lewis, "The Development of Responsible Government in the Northwest Territories 1976-1998" in Canadian Parliamentary Review, Summer 1998, Vol. 21 no.2 pp.12-17

Kevin O'Brien, "Some Thoughts on Consensus Government in Nunavut", Canadian Parliamentary Review, Vol. 26, No. 42003

Kevin O'Keefe, "Northwest Territories: Accommodating the Future", in Provincial and Territorial Legislatures in Canada, University of Toronto Press, Toronto, 1987, pp.207220.

John H. Parker, Arctic Power, The Cider Press, Peterborough Ontario, 1992

Chris Pearson, "Yukon's Responsible Government", in Canadian Parliamentary Review, vol. 3 , no. 1,1980

Graham White $a$, "Westminster in the Arctic: The Adaptation of British Parliamentarism in the Northwest Territories", Canadian Journal of Political Science, Vol. 24, no. 3 (Sept. 1991), pp.499-523

Graham White $b$, "Structure and Culture in a Non-Partisan Westminster Parliament: Canada's Northwest Territories", Australian Journal of Political Science, 28:2, pp.322339

Graham White $c$, “And Now For Something Completely Northern: Institutions of Governance in the Territorial North", Journal of Canadian Studies, Winter 2001; 35, 4, pp.80-99

History in the Making: Under Northern Skies, The Legislative Assembly of the Northwest Territories, a collection of essays by various authors familiar with the institution, published by the Legislative Assembly of the Northwest Territories, 1999 
Report of the Chief Plebiscite Officer, Elections NWT, June 1992

Official Voting Results, published by the Chief Electoral Officer of Canada in his capacity as Chief Electoral Officer for the Northwest Territories for the general territorial elections of:

1975

1979

1983

1987

1991

Official Voting Results, published by the Chief Electoral Officer of the Northwest Territories for the general territorial elections of:

1995

1999

2003

2007

Hansard of the Legislative Assembly of the Northwest Territories,

November 12, 1991

November 20, 1995

November 12, 1998

July 27, 1999

December 10, 2003

May 31, 2004

October 19,2006

August 17, 2007

February 15, 2008

Electoral Boundaries Commission Report 2006

Third Report of the Special Committee on Rules, Procedures and Privileges, $10^{\text {th }}$. Assembly, Ted Richard, Chairman

Friends of Democracy v. Northwest Territories (Commissioner) (1999) 171 D.L.R. $\left(4^{\text {th }}\right)$ 551 , s. 12 , accessed at http://www.canlii.org/en/nt/ntsc/doc/1999/1999canlii4256/1999canlii4256.html

Justice John Gomery, "Restoring Accountability: Report of the Commission of Inquiry into the Sponsorship Program and Advertising Activities", Government of Canada, 2006, chap. 10 accessed at http://epe.lac-bac.gc.ca/100/200/301/pco-bcp/commissionsef/sponsorship program-ef/phase2report/en/phase2report/recommendations/default.htm

Nunatsiavut Constitution, s.3.2.12

http://www.nunatsiavut.com/pdfs/Constitution.pdf 
The Inuvik Drum

- Editorial, "Right to Party"

November 19, 1999

http://www.nnsl.com/frames/newspapers/1999-11/nov19 99edit.html

News/North

- "An election like no other", by Jack Danylchuk Northern News Services, November 17, 2003

http://www.nnsl.com/frames/newspapers/2003-11/nov17 03elect.html

- Editorial, "Who's the Boss?",

October, 23, 2006, http://www.nnsl.com/frames/newspapers/2006-10/oct23 06edit.html

The Slave River Journal

- Editorial, "Consensus Government not a true Democracy"

October 3, 2007

http://www.sri.ca/default.asp?sourceid $=$ \&smenu=143\&twindow=Default\&mad= No\&sdetail $=2262 \&$ wpage $=1 \&$ skeyword $=\&$ sidate $=\&$ ccat $=\&$ ccatm $=\&$ restate $=\&$ re status $=$ \&reoption $=$ \&retype $=$ \&repmin $=\&$ repmax $=$ \&rebed $=$ \&rebath $=\&$ subname $=$ \& pform $=\& s c=1957 \& h n=$ srj\&he $=. c a$

The Yellowknifer

- "NDP enter race", by Glen Korstrom, Northern News Services

October 29, 1999

http://www.nnsl.com/frames/newspapers/1999-10/oct29 99ndp.html

- "Five Yellowknife candidates will run for MLA under NDP Platform"

Northern News Services, October 29, 1999

http:/www.nnsl.com/frames/newspapers/1999-10/oct29 99ndp.html

- Editorial, "Backroom Traditions Persist"

January 17,2000

http://www.nnsl.com/frames/newspapers/2000-01/jan17 00edit.html

- "Group ‘fed-up' with consensus" by Jack Danylchuk Northern News Services

June 25, 2003

http://www.nnsl.com/frames/newspapers/2003-06/jun25 03pol.html

- "Voters must pick Premier: Kakfwi", Northern News Services

November 26, 2003

http://www.nnsl.com/frames/newspapers/2003-11/nov26 03kak.html

CBC online NWT Votes 2007, http://www.cbc.ca/nwtvotes2007/ridings/

Legislative Assembly of the Northwest Territories website,

http://www.assembly.gov.nt.ca/ live/pages/wpPages/Committees.aspx

Website for the NWT Party

http://www.nwtparty.com/index.html 
Bank of Canada's Inflation Calculator

http://www.bank-banque-canada.ca/en/rates/inflation_calc.html

"Looking back, looking forward: Charles Dent is interviewed by Pearl Benyk", May 2007, posted on Dent's website at

http://www.charlesdent.com/news_letter/2007/june2007.pdf 